\title{
Evolution of fluid from the ultrahigh temperature lower crust to shallower levels: Constraints from silicate--oxide--sulphide-sulphate assemblages of mafic granulites of the Eastern Ghats Belt, India
}

\author{
Arnob Kumar Mondal and Sankar Bose* \\ Centre for Advanced Studies, Department of Geology, Presidency University, Kolkata 700 073, India. \\ *Corresponding author.e-mail: sankar.bose@gmail.com
}

MS received 22 May 2018; revised 24 November 2018; accepted 11 February 2019; published online 5 July 2019

Mafic granulites from key localities of the Eastern Ghats Province preserve $\mathrm{Fe}-\mathrm{Ti}$ oxides, $\mathrm{Cu}-\mathrm{Fe}$ sulphides and traces of sulphate minerals along with silicate phases. Two different varieties of mafic granulite exhibit slightly contrasting mineral assemblages. While the massive type of mafic granulite contains minerals assemblage orthopyroxene + clinopyroxene + plagioclase + magnetite + ilmenite + pyrite + pyrrhotite, the migmatitic variety contains garnet as an additional phase. Both oxide and sulphide minerals show contrasting textural characters. Textural analysis and construed mineral reactions imply that the variation of oxide-silicate, oxide-sulphide and sulphate relations is linked to variation of $f \mathrm{O}_{2}$ during the pre-peak, peak and post-peak stages of metamorphism. The calculated $f \mathrm{O}_{2}$ values range up to $+4 \log$ units relative to the QFM (quartz-fayalite-magnetite) buffer among the samples, except for one sample which shows lower values ( $-10 \log$ units relative to the FMQ (fayalite-magnetite-quartz) buffer). The consistently high $\mathrm{fO}_{2}$ condition at the lower crust could result from several factors, but the role of the externally derived fluid appears to be plausible. Hot brine solution with $\mathrm{CaCl}_{2}$ species can explain the oxidation as well as local metasomatism of the mafic lower crust even though its presence is not verified from direct characterisation like fluid inclusion analysis.

Keywords. Mafic granulite; oxygen fugacity; brine solution; external fluid; Eastern Ghats Belt.

\section{Introduction}

Opaque minerals like $\mathrm{Fe}-\mathrm{Ti}$ oxides, $\mathrm{Cu}-\mathrm{Fe}$ sulphides and graphite in granulite and amphibolite facies rocks can provide information on both temperature conditions and oxygen fugacity of the deep crust (Buddington and Lindsley 1964; Duchesne 1972; Bohlen and Essene 1977; Rollinson 1980; Frost and Chacko 1989). Assemblages like fayalitemagnetite-quartz, magnetite-haematite, orthopyroxene-magnetite-quartz (Frost et al. 1988; Harlov
1992, 2000a; Harlov et al. 1997) and pyrrhotite-pyrite-magnetite (Mohr and Newton 1983; Tracy and Robinson 1988; Cameron et al. 1993; Harlov et al. 1997; Harlov 2000b) are now reliably utilised to constrain the fluid activity during metamorphism. Compared to the oxide phases, sulphide minerals have received relatively less attention in granulite studies possibly due to the vulnerability of these minerals to retrograde reactions and also partly due to the lack of an established relationship between sulphide 
and common silicate and oxide minerals. Petrological information from regional granulite terranes like the Bamble Sector, Norway provides some constraints on textural relation among pyrrhotite, pyrite and magnetite from metabasites and mafic dikes (Cameron et al. 1993). Replacement of pyrrhotite and pyrite by magnetite in such rocks was achieved by interaction of highly oxygenated fluid, well above the FMQ buffer at deep crustal condition. Oxide and sulphide minerals in Rb-depleted Archaean granulites of the Shevaroy Hills Massif, South India bear the signature of a similar interaction of highly oxygenated fluid at a lower crust (Harlov et al. 1997). Although meagre in reported occurrences, these studies imply that high oxygen fugacity favours precipitation of pyrite over pyrrhotite (Harlov et al. 1997, 2005). It is thus evident that oxide-sulphide phase relations, in combination with silicate minerals, can help in elucidating the role of fluids in oxidising and/or reducing large regions of the lower crust during granulite facies metamorphism. Notably, mafic granulite has a bulk composition where oxide, sulphide and silicate minerals can coexist during a major part of the evolutionary history. Other minor species like the sulphates can also provide additional constraints on solid-fluid interaction, particularly at the later part of the evolution (Hanor 2000).

In this study, we document intricate textural features of silicate-oxide-sulphide mineral associations in mafic granulite samples collected from the Eastern Ghats Belt (EGB), India. Textural and compositional characteristics of these mineral associations have been used to understand the metamorphic history, particularly the fluid evolution during the peak and retrogressive stages.

\section{Geological setting}

The EGB, trending NE-SW along the east coast of the Indian peninsula, extends for a length over $1000 \mathrm{~km}$ (figure 1) and consists of high-grade orthogneisses (mafic granulite and charnockite

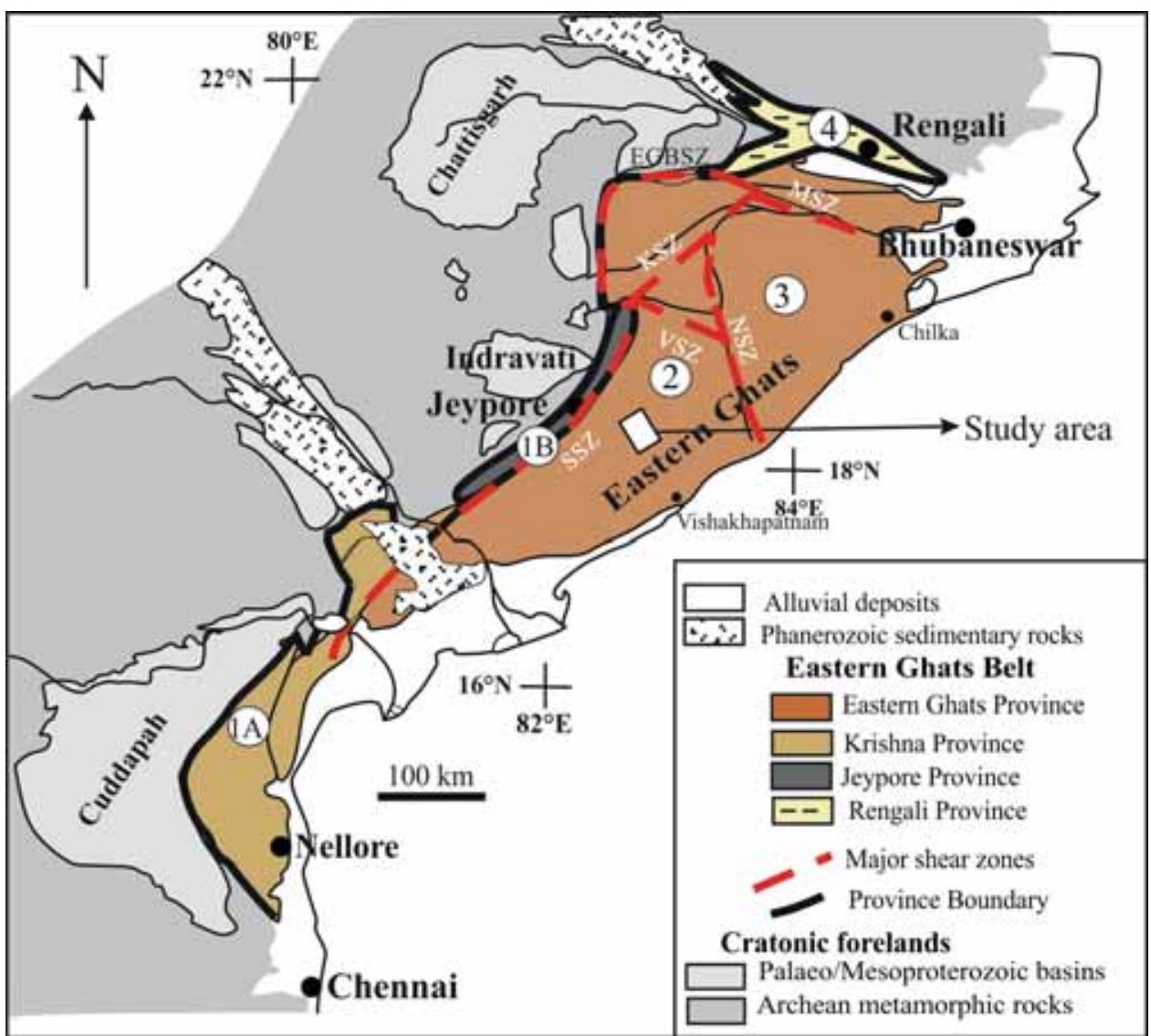

Figure 1. Generalised geological map of EGB showing the location of the study area. Subdivisions of the Eastern Ghats Province are given after Dobmeier and Raith (2003). Abbreviations used: MSZ: Mahanadi shear zone; VSZ: Vamshadhara shear zone; NSZ: Nagavalli shear zone; SSZ: Sileru shear zone; KSZ: Koraput-Sonepur shear zone; EGBSZ: Eastern Ghats Boundary shear zone. The numerical values inside the circle represent isotopic domain names after Rickers et al. (2001). 
gneiss) and paragneisses (pelitic granulite and calc-silicate granulite) along with intrusives of granitic, basic, alkaline and anorthositic rocks (Ramakrishnan et al. 1998). Numerous studies have shown that the EGB rocks preserve the evidence of an early ultrahigh temperature (UHT) metamorphism $\left(>900^{\circ} \mathrm{C}\right)$ at a pressure of $8-10$ kbar (Lal et al. 1987; Sengupta et al. 1990; Dasgupta et al. 1995; Bose et al. 2000, 2006; Bose and Das 2007; Das et al. 2011; Korhonen et al. 2013a; Ganguly et al. 2017) followed by near-isobaric cooling along an anticlockwise $P-T$ path (reviewed in Dasgupta et al. 2017). Recent reviews focus on the role of EGB during the assembly of supercontinents Columbia, Rodinia and Gondwana (Bose et al. 2011; Dasgupta et al. 2013, 2017). It is argued that the evolution of EGB took place by repeated subduction and accretion during the major part of the Proterozoic era (ca. 1.80-0.50 Ga; Dasgupta et al. 2013, 2017). While the pressure-temperature evolution of the EGB rocks has been deciphered with certainty (reviewed in Dasgupta et al. 2013, 2017), the role of the lower crustal fluid has not been described in detail except for a few occurrences
(Mohan et al. 2003; Sarkar et al. 2003; Bose et al. 2009, 2016; Ganguly et al. 2017). These latter studies show that high-density $\mathrm{CO}_{2}$ fluid $\left(>1.0 \mathrm{~g} / \mathrm{cm}^{3}\right)$ was responsible for dehydrating the lower crust and maintaining sustained high temperature conditions. Bose et al. (2009) studied oxide mineral assemblages from a suite of granulites and demonstrated how high oxygen fugacity was maintained throughout the evolutionary history of the lower crust. These studies mostly rely on fluid inclusion data and their direct implication on mineral assemblages represented by silicate and oxide phases. Sulphide phases represent important constituents of mafic granulites, but have not been explored so far from the EGB to characterise the fluid evolution history.

The samples of mafic granulite for the present study were collected from several locations along the Araku-Paderu transect (figure 2). These locations include Anantagiri (sample 17EG14; N18 $16^{\prime} 58.7^{\prime \prime}$ and E82 $57^{\prime} 45.3^{\prime \prime}$ ), Muliyaguda (sample 17EG16; N18 $14^{\prime} 28.8^{\prime \prime}$ and E83 $\left.01^{\prime} 49.6^{\prime \prime}\right)$ and Loteru (sample 9C; $\mathrm{N} 18^{\circ} 19^{\prime} 36.5^{\prime \prime}$ and E83 $04^{\prime} 22.5^{\prime \prime}$ ), all situated within the Visakhapatnam district

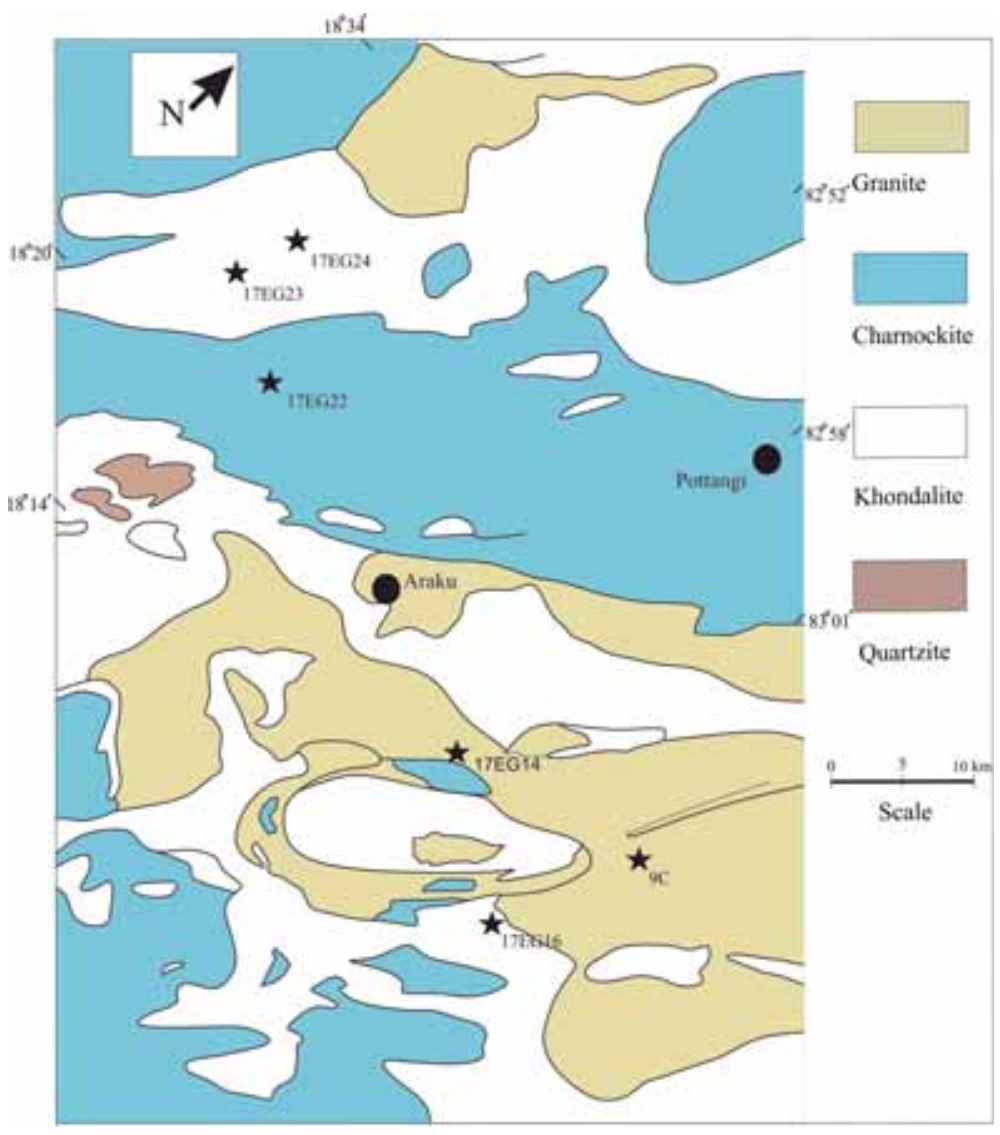

Figure 2. Broad geological map of part of the Eastern Ghats Province showing major lithological units and sample locations (modified after Ramakrishnan et al. 1998). 

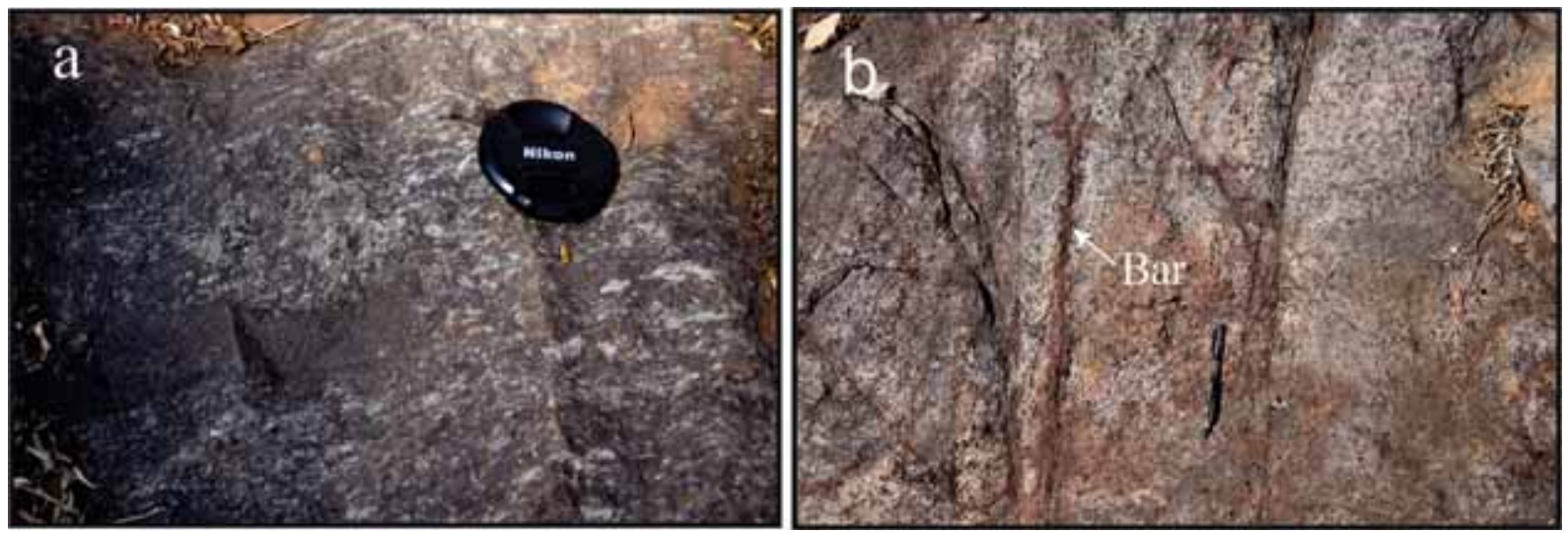

Figure 3. Field features of mafic granulite: (a) foliated and migmatitic appearance of mafic granulite. Note the presence of a mafic enclave within the rock and (b) patchy leucolayer in the migmatitic mafic granulite.

of Andhra Pradesh. The other locations include Duruva (sample 17EG22; N18 $21^{\prime} 36.2^{\prime \prime}$ and E82 ${ }^{\circ}$ 44'29.1'), Arlaput (sample 17EG23; N18 $24^{\prime}$ 06.3" and $\mathrm{E} 82^{\circ} 40^{\prime} 34.4^{\prime \prime}$ ) and Balda (sample 17EG24; N18 $26^{\prime} 41.8^{\prime \prime}$ and E82 $40^{\prime} 52.2^{\prime \prime}$ ), situated within the Koraput district of Odisha (figure 2). Petrological data from the Anantagiri area suggest that UHT metamorphism occurred at 8-9 kbar pressure along an anticlockwise $P-T$ path (Sengupta et al. 1990; Korhonen et al. 2013a). The sample 17EG14 was collected from the very locality from where the UHT aluminous granulite was reported. Aluminous granulite from the Loteru area showed UHT metamorphism unveiled from textural features of aluminous orthopyroxene (Bose et al. 2006). The present sample (sample EG 9C) was collected from the same locality where aluminous granulite reported by Bose et al. (2006) occurs. These two samples, along with the one exposed near Muliyaguda, are massive in appearance. On the other hand, mafic granulite from the Duruva area is foliated in nature but mafic granulite from Arlaput and Balda are both foliated and migmatitic in appearance (figure 3a). The leucosome layer within the migmatitic mafic granulite occurs as irregular patches and lenses, up to $3 \mathrm{~cm}$ in width. Occasionally, the leucosome part is patchy for the Balda sample where mm-thick fractures develop (figure $3 \mathrm{~b}$ ). These fractures are filled by barite as revealed from a petrographic study described later. In all the occurrences, the mafic granulite is hosted within foliated charnockite gneiss. The general trend of the foliation varies from NE-SW near Anantagiri and Duruva to NW-SE near Muliyaguda and N-S near the Arlaput-Balda area.

\section{Petrography}

\subsection{Silicate-oxide phases}

We have subdivided the mafic granulites into two distinct assemblages based on mineralogy as described below.

3.1a Assemblage A. Mafic granulite samples from the Anantagiri, Muliyaguda, Loteru and Duruva areas show similar assemblages comprising orthopyroxene, clinopyroxene, plagioclase, K-feldspar, \pm hornblende, biotite, ilmenite, apatite \pm magnetite and sulphides. Overall, these phases show a granoblastic texture. Both ilmenite (Ilm) and

Figure 4. Photomicrographs and BSE images of mafic granulite assemblage $\mathrm{A}$ : (a) magnetite $\left(\mathrm{Mag}_{4}\right)$ vein within plagioclase $(\mathrm{Plg})$ in association with orthopyroxene $(\mathrm{Opx})$ and clinopyroxene (Cpx), (b) thin film of K-feldspar (Kfs) along the margin of orthopyroxene (Opx), (c) ilmenite $\left(\mathrm{Ilm}_{2}\right)$ occurring along the margin of orthopyroxene (Opx) and antiperthitic K-feldspar (Kfs) within deformed plagioclase $(\mathrm{Plg}),(\mathbf{d})$ ilmenite $\left(\mathrm{Ilm}_{2}\right)$ partially engulfs magnetite $\left(\mathrm{Mag}_{2}\right)$, (e) fine trellis haematite (Haem) intergrowth within ilmenite $\left(\mathrm{Ilm}_{2}\right)$, (f) haematite (Haem) lamellae within ilmenite $\left(\mathrm{Ilm}_{2}\right)$, associated $\mathrm{Mag}_{4}$ vein partially rims pyrrhotite $(\mathrm{Po})$ and chalcopyrite $(\mathrm{Cp}),(\mathrm{g})$ tripartite grain of magnetite $\left(\mathrm{Mag}_{2}\right)$, haemo-ilmenite $\left(\mathrm{Ilm}_{2}\right)$ and pyrite $(\mathrm{Py})$ in association with plagioclase $(\mathrm{Plg})$ and orthopyroxene (Opx), (h) magnetite $\left(\mathrm{Mag}_{1}\right)$ inclusion within clinopyroxene (Cpx). Note the thin rim of quartz (Qtz) separating the two. (i) Tiny grains of orthopyroxene (Opx) along the margin of hornblende (Hbd). (j) Bipartite grain of magnetite $\left(\mathrm{Mag}_{2}\right)$ and ilmenite $\left(\mathrm{Ilm}_{2}\right)$. (k) Myrmekitic intergrowth of plagioclase (Plg) and quartz (Qtz) at the margin of perthite (Kfs). (1) Cuspate grain boundaries of K-feldspar (Kfs) and quartz (Qtz) in the leucosome layer (shown in arrows) of migmatitic mafic granulite. 

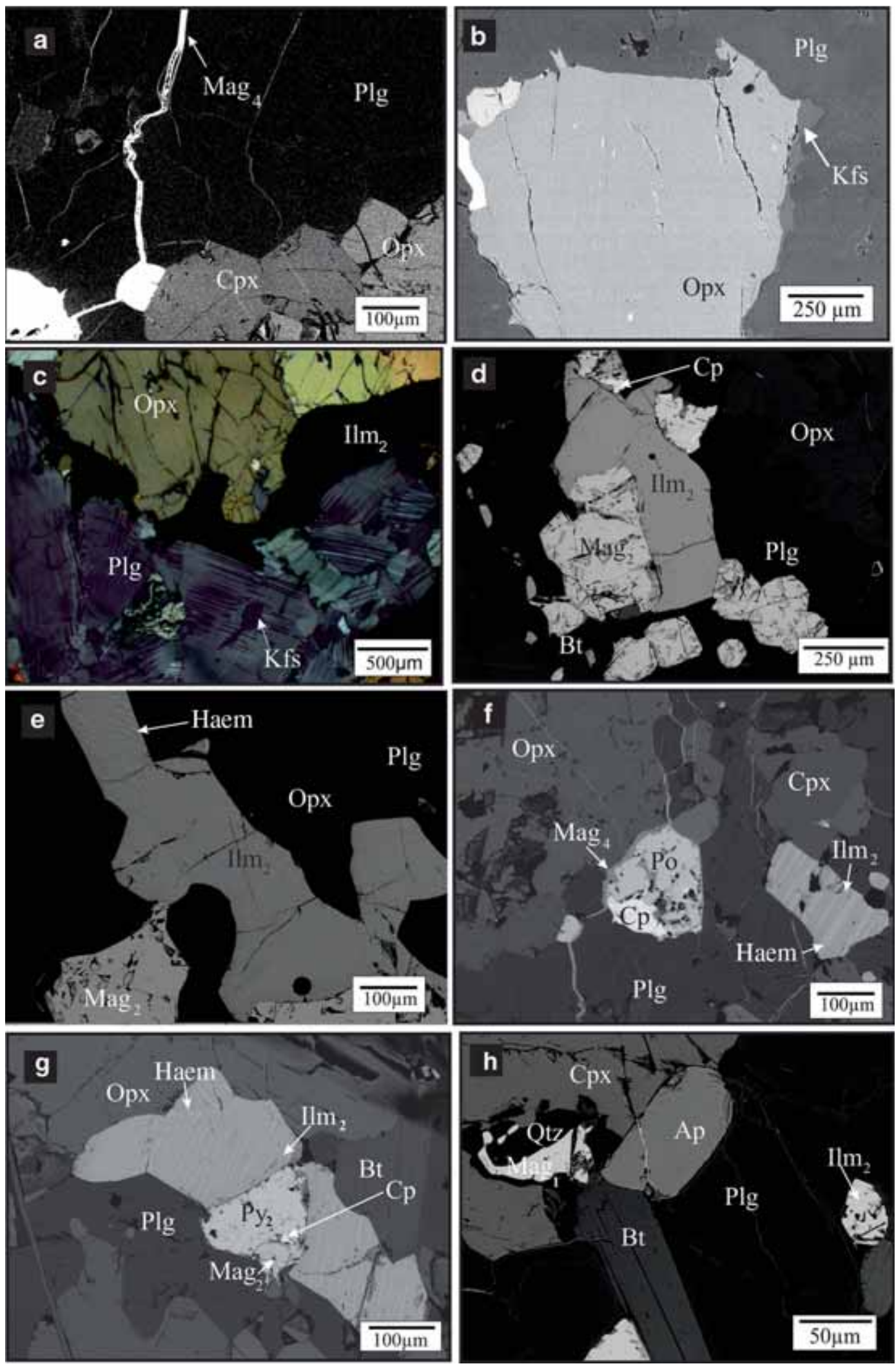

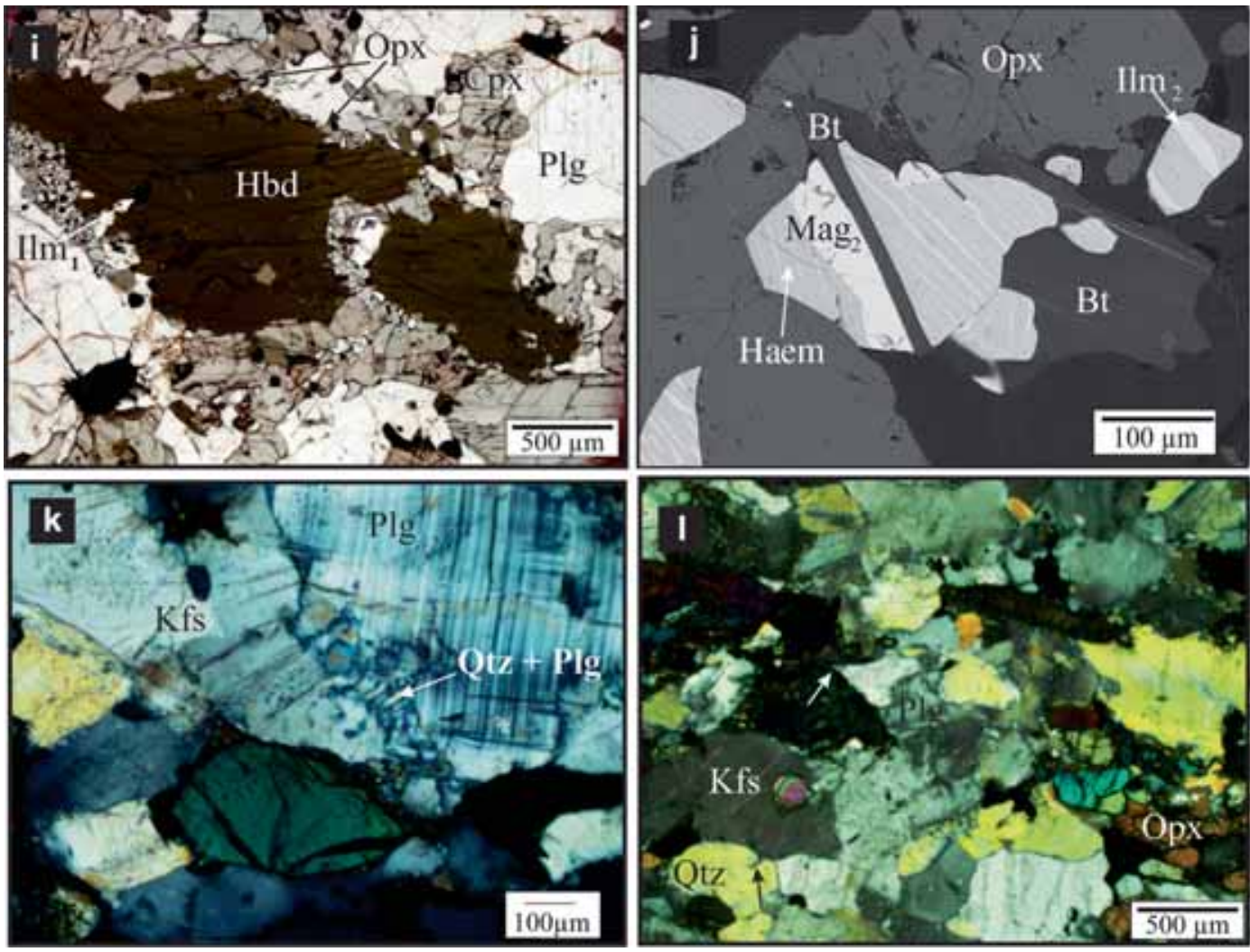

Figure 4. (Continued.)

magnetite (Mag) grains locally show different modes of occurrences. We have classified them as: (i) oxide phases occurring as inclusion within the porphyroblasts, termed as $\mathrm{Ilm}_{1}$ and $\mathrm{Mag}_{1}$; (ii) oxide phases adjacent to porphyroblastic phases and as discrete grains, termed as $\mathrm{Ilm}_{2}$ and $\mathrm{Mag}_{2}$; (iii) magnetite occurring with the sulphide phase like pyrite replacing pyrrhotite, termed as $\mathrm{Mag}_{3}$; and (iv) fracture filling magnetite vein, termed as $\mathrm{Mag}_{4}$ (2-6 $\mu \mathrm{m}$ thickness, figure 4a).

In sample 17EG14, both orthopyroxene and clinopyroxene contain exsolved lamellae while discrete ilmenite $\left(\mathrm{Ilm}_{2}\right)$ grains are mostly free of exsolved lamellae. Plagioclase grains are porphyroblastic, containing deformed twin lamellae. Locally, these are recrystallised to smaller strainfree grains along the margin. Sometimes K-feldspar micro-veins occur along the grain boundaries of plagioclase. A discontinuous thin film of K-feldspar occurs along the margin of pyroxene grains (figure 4b). $\operatorname{Ilm}_{2}$ (>400 $\mu \mathrm{m}$ along the maximum dimension) occurs adjacent to porphyroblastic orthopyroxene and clinopyroxene grains (figure 4c). Antiperthite texture is shown by patches of $\mathrm{K}$ feldspar in plagioclase (figure 4c). Myrmekitic intergrowth is formed along the boundary between $\mathrm{K}$-feldspar and plagioclase.
The same assemblage in the sample 17EG16 shows recrystallisation and the rock exhibits a weak gneissic fabric. Marginal granulation and stretching along the foliation of the porphyroblastic grains are common features. Smaller feldspar grains also show recrystallisation with annealed polygonal grain boundaries. A notable feature of this assemblage is the occurrence of exsolved haematite lamellae in ilmenite (haemo-ilmenite: $\mathrm{Ilm}_{2}$ ) along with some discrete lamellae-free $\mathrm{Ilm}_{2}$ and $\mathrm{Mag}_{2}$. Locally, $\mathrm{Ilm}_{2}$ (lamellae-free) grains partially engulf granular $\mathrm{Mag}_{2}$ (figure 4d). At places, fine trellis intergrowth (not covering the entire grain) of haematite is also observed in $\mathrm{Ilm}_{2}$ which shares grain contact with $\mathrm{Mag}_{2}$ (figure 4e). On the other hand, $\operatorname{Ilm}_{2}$ in contact with porphyroblastic pyroxene exhibits up to two generations of exsolved lamellae (figure 4f). $\mathrm{Mag}_{2}$ (3-10 $\mu \mathrm{m}$ thickness, figure $4 \mathrm{~g}$ ) often occurs as tripartite grains along with haemo-ilmenite and pyrite within the feldspathic matrix. Locally, inclusions of both $\mathrm{Mag}_{1}$ and $\mathrm{Ilm}_{1}$ (lamellae-free) occur within porphyroblastic clinopyroxene where these are separated from the host by a quartz rim (figure 4h).

Sample 9C contains hornblende in the mineral assemblage. Porphyroblastic orthopyroxene grains 

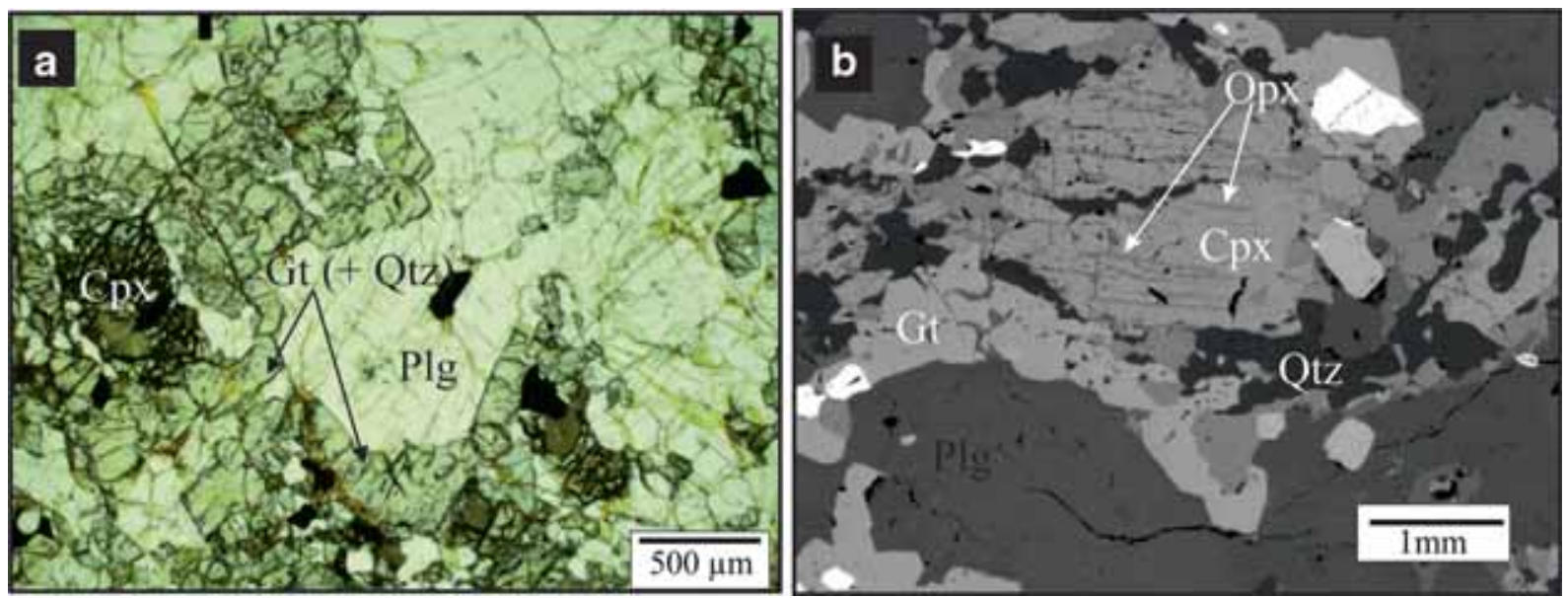

Figure 5. Photomicrograph and BSE image of the mafic granulite assemblage B: (a) garnet (Gt) corona along with quartz $(\mathrm{Qtz})$ around clinopyroxene ( $\mathrm{Cpx})$ and $(\mathbf{b})$ porphyroblastic clinopyroxene $(\mathrm{Cpx})$ contains exsolved lamellae of orthopyroxene $(\mathrm{Opx})$.

are subidioblastic, containing the inclusion of small biotite and hornblende grains. Hornblende also occurs as patches on porphyroblastic orthopyroxene. Tiny recrystallised orthopyroxene grains occur along grain boundaries of biotite and porphyroblastic hornblende (figure 4i). $\mathrm{Ilm}_{1}$ grains are present as inclusion within porphyroblastic phases and contain haematite exsolution lamellae. Bipartite grains of $\mathrm{Mag}_{2}$ with $\mathrm{Ilm}_{2}$ (with exsolved haematite) are found along the margin of porphyroblastic orthopyroxene grains but $\mathrm{Mag}_{2}$ occurrences close to patchy hornblende and retrograde biotite are a notable feature (figure $4 \mathrm{j}$ ).

The sample 17EG22 shows a gneissic fabric. Orthopyroxene and clinopyroxene grains contain exsolved lamellae of each other. Marginal granulation of porphyroblastic phases is common. Perthitic feldspar shows a myrmekitic texture (figure $4 \mathrm{k}$ ). Cuspate grains of quartz and feldspar in the leucosome layer are present (figure $4 \mathrm{l}$ ). $\mathrm{Ilm}_{2}$ grains are free of exsolved haematite. No discrete $\mathrm{Mag}_{2}$ is present in this sample, but $\mathrm{Mag}_{3}$ grains are locally found in contact with pyrite.

$3.1 b$ Assemblage B. Mafic granulite samples 17E G23 and 17EG24 contain garnet in addition to orthopyroxene, clinopyroxene, plagioclase and ilmenite as a porphyroblastic phase along with quartz, K-feldspar, sulphide and sulphate phases and a trace amount of calcite. The leucocratic layer is composed of quartz, K-feldspar and plagioclase, while the melanocratic layer contains garnet, orthopyroxene and clinopyroxene. Garnet occurs in two textural modes: (i) as a porphyroblast (sample 17EG23) and (ii) as a reaction corona with or without intergrown quartz separating porphyroblastic orthopyroxene and clinopyroxene from plagioclase (figure 5a) in sample 17EG24. Evidences of grain-scale deformation like recrystallisation and formation of quartz ribbon, deformed feldspar grains and a relatively stretched nature of the porphyroblastic phases are prominent. Clinopyroxene grains show exsolved lamellae of orthopyroxene (figure 5b). Discrete grain of $\mathrm{Ilm}_{2}$ is free of exsolved haematite. Discrete $\mathrm{Mag}_{2}$ grain is absent, but $\mathrm{Mag}_{4}$ occurs along the fractures. Sulphide grains are rare.

\subsection{Oxide-sulphide phases}

Three different types of sulphide phases are present: pyrrhotite $(\mathrm{Po})$, pyrite $(\mathrm{Py})$ and chalcopyrite $(\mathrm{Cp})$. Both Py and Cp grains occur in association with Po grains. Texturally, two different types of pyrite are present in the assemblages. Larger pyrite grains $\left(\mathrm{Py}_{1}\right)$ share equilibrium contacts with $\mathrm{Ilm}_{2}$ and $\mathrm{Mag}_{2}$ forming the peak metamorphic assemblage (figure $6 \mathrm{a})$. The other variety of pyrite $\left(\mathrm{Py}_{2}\right)$ occurs as a replacement along the margin of Po, with or without $\mathrm{Mag}_{3}$. In sample 17EG14, Po is the dominant sulphide phase. Locally, $\mathrm{Py}_{1}$ occurs as a relict within the Po grains wherein exsolved blebs of $\mathrm{Cp}$ are notable (figure 6b). All these sulphide phases occur in association with exsolution-free $\mathrm{Ilm}_{2}$. No magnetite grain (in any mode) occurs in association with sulphide phases in sample 17EG14. On the other hand, Py dominates over Po in sample 17EG16 where $\mathrm{Cp}$ is the other sulphide phase. Po occurs as a relict within the $\mathrm{Py}_{2}$ or is replaced by both $\mathrm{Py}_{2}$ and $\mathrm{Mag}_{3}$ (figure 6c). Here, both $\mathrm{Py}_{2}$ and 

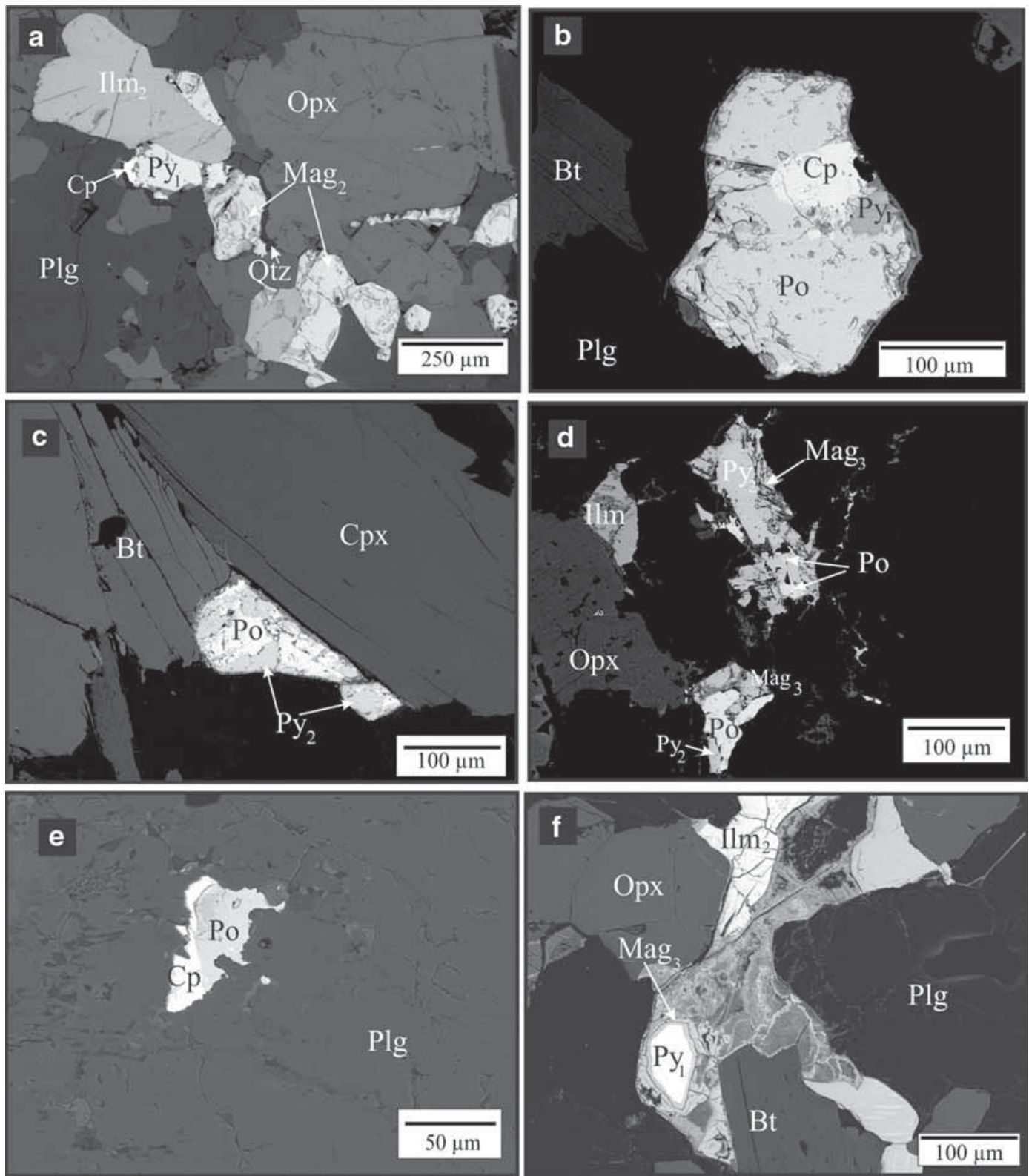

Figure 6. BSE images showing oxide and sulphide phases of mafic granulite: (a) pyrite $\left(\mathrm{Py}_{1}\right)$ in equilibrium contact with ilmenite $\left(\mathrm{Ilm}_{2}\right)$ and magnetite $\left(\mathrm{Mag}_{2}\right)$, (b) relic pyrite $\left(\mathrm{Py}_{1}\right)$ within pyrrhotite $(\mathrm{Po})$. Also note the tongue of chalcopyrite $(\mathrm{Cp})$ in Po. (c) Pyrite $\left(\mathrm{Py}_{2}\right)$ marginally replaces pyrrhotite $(\mathrm{Po}),(\mathbf{d})$ pyrrhotite $(\mathrm{Po})$ is completely replaced by pyrite $\left.(\mathrm{Py})_{2}\right)$ and magnetite $\left(\mathrm{Mag}_{3}\right)$. Note the relic of Po within $\mathrm{Py}_{2}$. (e) Pyrrhotite (Po) and chalcopyrite (Cp) share a convolute mutual boundary within plagioclase $(\mathrm{Plg})$ and $(\mathbf{f})$ mantle of magnetite $\left(\mathrm{Mag}_{3}\right)$ on pyrite $\left(\mathrm{Py}_{1}\right)$.

$\mathrm{Cp}$ are associated with the haemo-ilmenite $\left(\mathrm{Ilm}_{2}\right)$ and magnetite $\left(\mathrm{Mag}_{2}\right)$ grain within the silicates (figure $4 \mathrm{~g}$ ). Intergranular fracture filling veins of $\mathrm{Mag}_{4}(2-4 \mu \mathrm{m}$ thickness) often partially engulf Po grains. In sample 17EG22, sulphide phases (dominated by $\mathrm{Po}$ ) occur in close association with $\mathrm{Ilm}_{2}$. At places, $\mathrm{Py}_{2}$ and $\mathrm{Mag}_{3}$ are found to replace $\mathrm{Po}$ (figure $6 \mathrm{~d}$ ). Locally, $\mathrm{Cp}$ and Po show a convolute mutual boundary (figure 6e). Sample 9C contains $\mathrm{Py}$ and $\mathrm{Cp}$ with the rare occurrence of Po. A notable feature is the patchy alteration of $\mathrm{Py}$ to a mixture of $\mathrm{K}, \mathrm{Fe}, \mathrm{Si}, \mathrm{Al}, \mathrm{S}$ (confirmed by SEMEDS analysis). Tiny grains of $\mathrm{Py}$ and $\mathrm{Cp}$ occur as relics within this alteration while $\mathrm{Py}_{1}$ occurs with a mantle of $\mathrm{Mag}_{3}$ (figure 6f). In assemblage B (samples 17EG23 and 17EG24), sulphide phases are less prominent. Locally, $\mathrm{Py}_{2}$ grains are found along with $\mathrm{Mag}_{3}$ in a quartzofeldspathic matrix containing relicts of both $\mathrm{Cp}$ and Po. Fracture filling veins of $\mathrm{Mag}_{4}$ and $\mathrm{Mag}_{3}$ rims over $\mathrm{Py}_{2}$ are 
common. Locally, $\mathrm{Py}_{2}$ veins (patchy) occur along intragranular fractures of plagioclase.

On the basis of textural characters, we have classified two sulphide-oxide associations

1. Py-dominated association where Po occurs as relicts within Py; magnetite vein $\left(\mathrm{Mag}_{4}\right)$ is replaced by pyrite; $\mathrm{Py}_{2}$ rims form over $\mathrm{Po}$; and haemo-ilmenite $\left(\mathrm{Ilm}_{2}\right)$ occurs as discrete grains.

2. Po-dominated association where discrete Po grains occur in association with plagioclase and $\mathrm{Ilm}_{2} ; \mathrm{Py}_{1}$ occurs as a relict within Po, with no discrete $\mathrm{Mag}_{2}$ or lamellae of haematite within $\mathrm{Ilm}_{2}$.

Chalcopyrite is common in both the associations.

\subsection{Sulphide-sulphate phases}

Barite occurs in association with pyrite $\left(\mathrm{Py}_{1}\right.$, $\left.\mathrm{Py}_{2}\right)$ in sample 17EG24. It occurs in three textural modes: (i) replacement of Py grains within plagioclase (figure 7a), (ii) discrete grain within calcite along the quartz-feldspar grain contact (figure $7 \mathrm{~b}$ ) and (iii) thin vein (width varies from 2 to $5 \mu \mathrm{m}$ ) within plagioclase and K-feldspar (figure 7c). Locally, Fe-oxide inclusions are present within barite. A partial rim of barite also occurs surrounding minute sulphide-sulphate mixes whose compositions were only identified from EDS analysis.

\section{Mineral chemistry}

All minerals were analysed using a CAMECA SX100 electron microprobe at the Indian Institute of Technology, Kharagpur, India. The instrument was operated at $15 \mathrm{kV}$ acceleration voltage using $12 \mathrm{nA}$ current. One micrometre probe diameter for the spot size was used for the point analyses. Natural silicate and oxide standards were used for calibration, except for $\mathrm{Ti}$ and $\mathrm{Mn}$ (synthetic standard material used). For sulphide mineral characterisation, we used a Vega-Tescan scanning electron microscope at the Presidency University and EDS data were acquired for spots to identify the elements within pyrite and pyrrhotite grains in different samples.

\subsection{Assemblage A}

Orthopyroxene in sample 17EG14 is slightly Mg-rich $\left(X_{\mathrm{Mg}}=0.53-0.55\right)$ and contains (0.98$1.21 \mathrm{wt} \% \mathrm{Al}_{2} \mathrm{O}_{3}$; table 1$)$. Clinopyroxene is magnesian too $\left(X_{\mathrm{Mg}}=0.70\right)$ and shows a decrease in
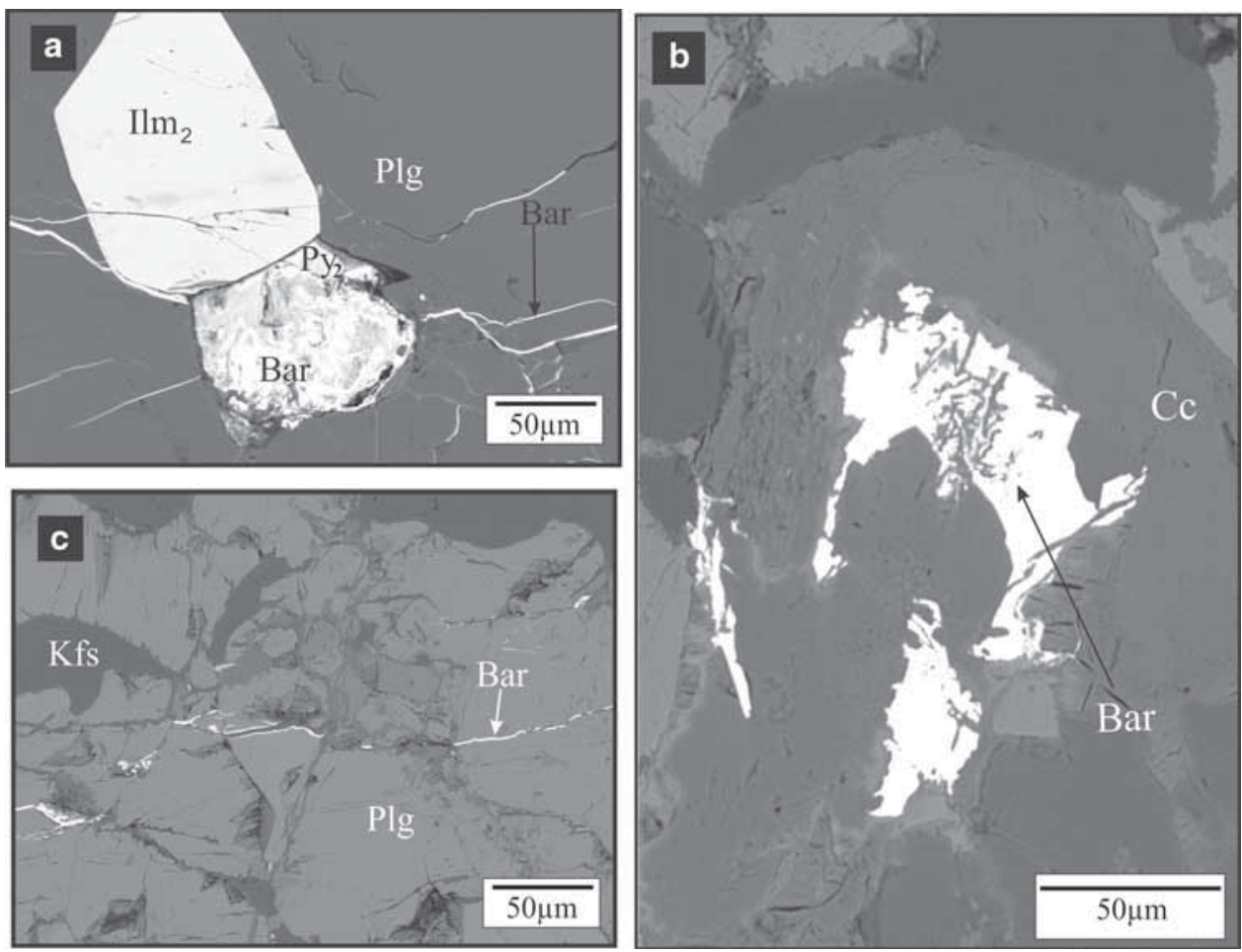

Figure 7. BSE images showing oxide, sulphide and sulphate phases of mafic granulite: $(\mathbf{a})$ pyrite $\left(\mathrm{Py}_{2}\right)$ in contact with ilmenite $\left(\mathrm{Ilm}_{2}\right)$ is partially replaced by barite (Bar). Note the presence of thin veins containing Bar. (b) Discrete grain of calcite $(\mathrm{Cc})$ and barite $(\mathrm{Ba})$ in the matrix. (c) Thin barite (Bar) vein cutting through plagioclase (Plg). 
alumina content from core $(2.28 \mathrm{wt} \%)$ to rim $(1.67$ wt\%). Plagioclase is calcic $\left(X_{\mathrm{An}}=0.73\right)$. Ilmenite $\left(\mathrm{Ilm}_{2}\right)$ grains contain low but variable haematite $\left(X_{\text {Haem }}=0.05\right)$ and geikielite $\left(X_{\text {Geik }}=0.03\right)$ components. $\mathrm{Ilm}_{2}$ grains contain $\mathrm{Ba}(0.87-1.12 \mathrm{wt} \%$ $\mathrm{BaO})$. Exsolved pyroxene lamellae are too thin to be analysed. K-feldspar patch (up to $0.68 \mathrm{wt} \%$ $\mathrm{BaO}$ ) within plagioclase shows patchy zoning as revealed in X-ray mapping (figure 8a and b). Naloss has occurred along the boundary of patchy K-feldspar with concomitant Ca gain. K-feldspar micro-veins show slightly high $\mathrm{Ba}$ concentration (up to $0.96 \mathrm{wt} \% \mathrm{BaO}$ ).

Orthopyroxene $\left(X_{\mathrm{Mg}}=0.57-0.59\right)$ in sample 17EG16 shows slight Al-enrichment from core (1.21 $\mathrm{wt} \%)$ to $\operatorname{rim}(1.41 \mathrm{wt} \%)$. Clinopyroxene $\left(X_{\mathrm{Mg}}=\right.$ $0.75)$ shows a decrease in $\mathrm{Al}$ content from core (3.15 wt\%) to rim (2.74 $\mathrm{wt} \%)$. Plagioclase is Carich $\left(X_{\mathrm{An}}=0.72\right)$. Ilmenite $\left(\operatorname{Ilm}_{2}\right)$ contains a small haematite fraction $\left(X_{\mathrm{Haem}}=0.3-0.4\right)$, which is similar to the ferrosilite component in orthopyroxene $\left(X_{\mathrm{Fe}}=0.42\right)$. The Geikielite component is minor $\left(X_{\text {Geik }}=0.035-0.046\right)$, but ilmenite contains $\mathrm{Ba}$ (0.85-0.96 wt\% $\mathrm{BaO}) . \mathrm{Ilm}_{1}$ also shows a similar composition. Magnetite inclusion $\left(\mathrm{Mag}_{1}\right)$ within clinopyroxene as well as discrete magnetite $\left(\mathrm{Mag}_{2}\right)$ grains shows a similar chromium content (0.37-0.36 wt\% $\left.\mathrm{Cr}_{2} \mathrm{O}_{3}\right)$ while the magnetite rim $\left(\mathrm{Mag}_{3}\right)$ contains a higher $\mathrm{Cr}$ content $\left(0.64\right.$ wt\% of $\left.\mathrm{Cr}_{2} \mathrm{O}_{3}\right)$. Magnetite vein $\left(\mathrm{Mag}_{4}\right)$ shows a very low $\mathrm{Cr}$ content (0.02 wt\% $\left.\quad \mathrm{Cr}_{2} \mathrm{O}_{3}\right)$. Magnetite $\left(\mathrm{Mag}_{1}\right)$ inclusion within clinopyroxene shows a slightly higher $\mathrm{Ti}$ content (table 1) compared to $\mathrm{Mag}_{2}$ and magnetite vein $\left(\mathrm{Mag}_{4}\right)$.

In sample $9 \mathrm{C}$, both orthopyroxene $\left(X_{\mathrm{Mg}}=\right.$ $0.61)$ and clinopyroxene $\left(X_{\mathrm{Mg}}=0.77-0.81\right)$ show Al-enrichment from core to rim (1.44-1.51 wt\% $\left.\mathrm{Al}_{2} \mathrm{O}_{3}\right)$. Plagioclase is Ca-rich $\left(X_{\mathrm{An}}=0.81\right)$. Hornblende (magnesio-hastingsite) shows a slight Mg-enrichment from core to $\operatorname{rim}\left(X_{\mathrm{Mg}}=0.64-\right.$ $67)$. Patchy hornblende is usually more magnesian. Ilmenite contains an appreciable amount of haematite $\left(X_{\text {Haem }}=0.11\right)$, but a low geikielite component $\left(X_{\text {Geik }}=0.02\right)$. Ilmenite lamellae within haematite also contains $\mathrm{Ba}(0.84-0.88 \mathrm{wt} \%$ $\mathrm{BaO})$. Late biotite is magnesian $\left(X_{\mathrm{Mg}}=0.71\right)$.

Orthopyroxene in sample 17EG22 is less magnesian $\left(X_{\mathrm{Mg}}=0.45\right)$ and alumina content shows enrichment from core to rim (0.9-1.3 wt\% $\left.\mathrm{Al}_{2} \mathrm{O}_{3}\right)$. Clinopyroxene $\left(X_{\mathrm{Mg}}=0.64\right)$ shows a higher alumina content at core. Plagioclase is anorthite-rich $\left(X_{\mathrm{An}}=0.60\right)$. K-feldspar in antiperthite is Na-poor but contains slightly higher $\mathrm{Na}$ when it occurs as a host in perthite $\left(X_{\mathrm{Ab}}=0.11\right)$. Ilmenite contains low $\mathrm{Fe}^{3+}\left(X_{\mathrm{Haem}}=0.03\right)$ and $\mathrm{Mg}$ $\left(X_{\text {Geik }}=0.01\right)$. A small amount of $\mathrm{Ba}$ is present in this mineral (0.87-0.94 wt\% $\mathrm{BaO})$.

Pyrrhotite grains contain no other elements like $\mathrm{Zn}$ or $\mathrm{Cu}$ (table 2 ). $X_{\mathrm{FeS}}$ contents of the analysed spots were calculated as 0.88 .

\subsection{Assemblage $B$}

In sample 17EG23, compositional variation in porphyroblastic garnet is represented as $\mathrm{Alm}_{58-59}$ $\operatorname{Prp}_{18-19} \mathrm{Grs}_{18-19} \mathrm{Sps}_{2-3}$. Plagioclase shows a decrease in anorthite component from core $\left(X_{\mathrm{An}}=\right.$ $0.42)$ to $\operatorname{rim}\left(X_{\mathrm{An}}=0.39\right)$ (table 3$)$. Clinopyroxene is magnesian $\left(X_{\mathrm{Mg}}=0.74\right)$ and alumina content is variable $\left(1.54-1.73 \mathrm{wt} \% \mathrm{Al}_{2} \mathrm{O}_{3}\right)$. Ilmenite contains $\mathrm{Ba}(0.94$ wt\% $\mathrm{BaO})$, minor haematite $\left(X_{\text {Haem }}=0.02\right)$ but an appreciable geikielite component $\left(X_{\mathrm{Geik}}=0.24\right)$. Biotite $\left(X_{\mathrm{Mg}}=0.7\right)$ inclusion within garnet shows a high Ti content (up to $5.4 \mathrm{wt} \%$ ). Garnet in sample 17EG24 has composition $\mathrm{Alm}_{58-60} \operatorname{Prp}_{16-19} \mathrm{Grs}_{17-19} \mathrm{Sps}_{2}$. Plagioclase composition is variable $\left(\mathrm{Ab}_{42-59} \mathrm{An}_{39-52} \mathrm{Or}_{1-2}\right)$, with calcic core $\left(X_{\mathrm{An}}=0.52\right)$ and less calcic rim $\left(X_{\mathrm{An}}=0.42\right)$. Clinopyroxene is magnesian $\left(X_{\mathrm{Mg}}=\right.$ $0.71-0.77)$ and shows a rimward decrease in alumina content. Ilmenite contains a low but variable haematite $\left(X_{\text {Haem }}=0.03-0.06\right)$, geikielite component $\left(X_{\text {Geik }}=0.04\right)$ as well as a decrease in $\mathrm{BaO}$ content from core to rim. Patchy zoning in plagioclase at the contact of perthitic feldspar is revealed from $\mathrm{Ca}$ and $\mathrm{Na}$ element mapping (figure 8).

\section{Evolution of mineral assemblages}

Evolution of the two mineral assemblages can be best described by the sequential appearance of silicate, oxide and sulphide minerals through mineral reactions. Garnet is the most important silicate mineral that appears only in assemblage B.

The peak mineral association in assemblage A is represented by orthopyroxene, clinopyroxene, plagioclase, K-feldspar, ilmenite $\left(\mathrm{Ilm}_{2}\right)$, magnetite $\left(\mathrm{Mag}_{2}\right)$ and sulphide minerals $\left(\mathrm{Py}_{1}, \mathrm{Po}\right.$ and $\left.\mathrm{Cp}\right)$.

Ilmenite in assemblage A mostly occurs as discrete grain $\left(\mathrm{Ilm}_{2}\right)$ and free of exsolved haematite in contact with pyroxene grains in samples 17EG14 and 17EG22. Both these samples are devoid of discrete magnetite $\left(\mathrm{Mag}_{2}\right)$ grains. The same feature is notable for assemblage $\mathrm{B}$ also. These 


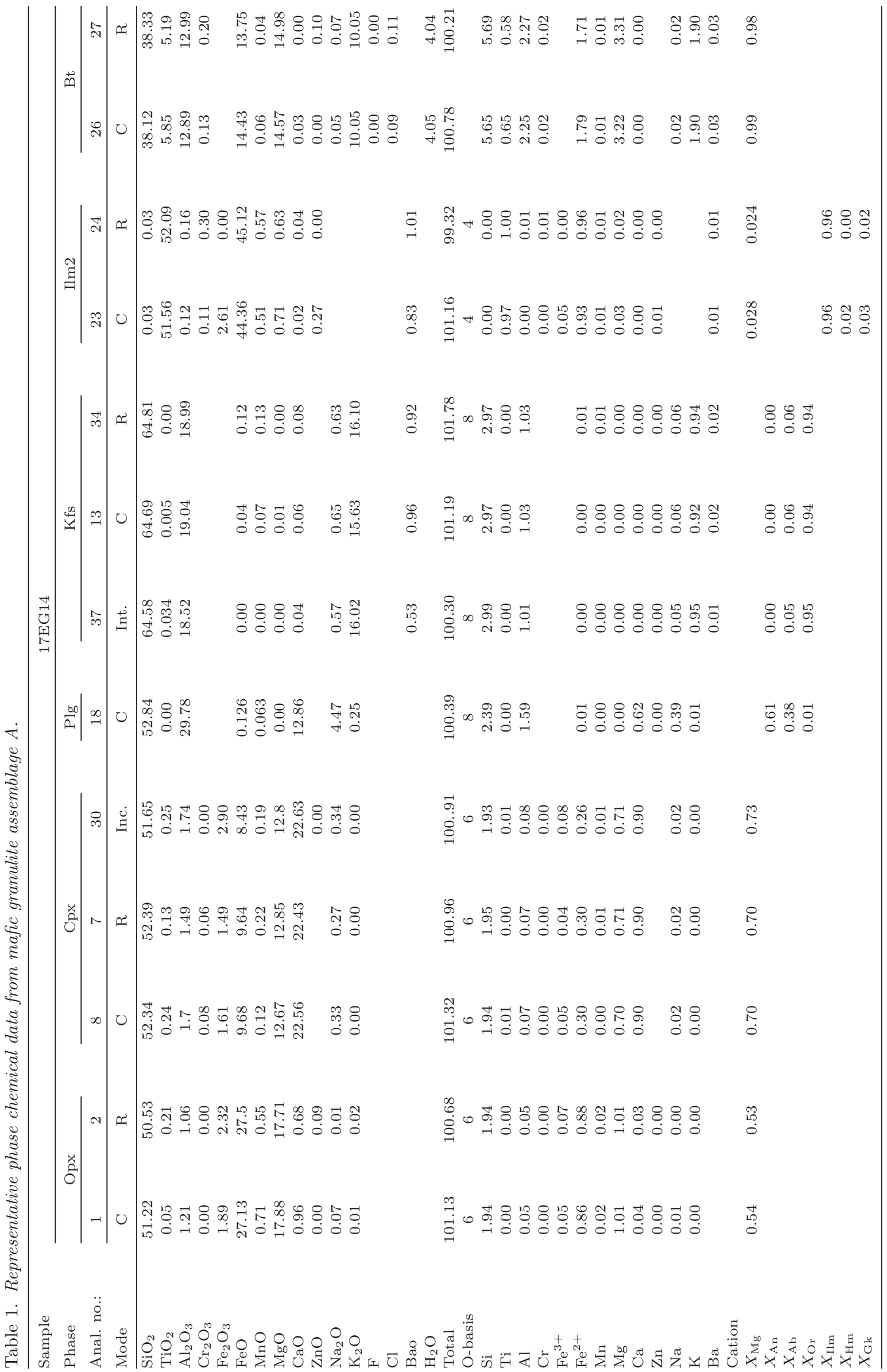




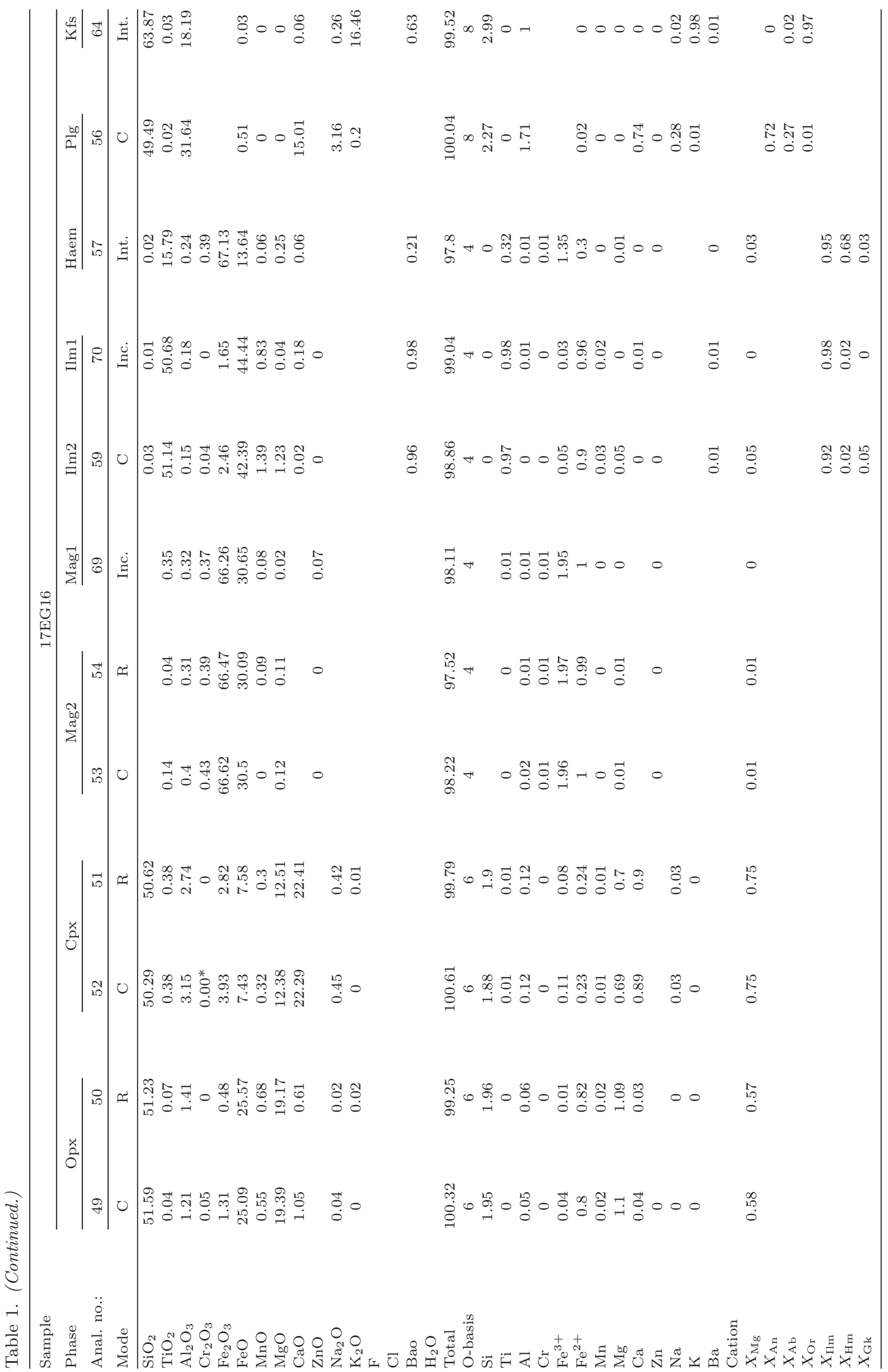




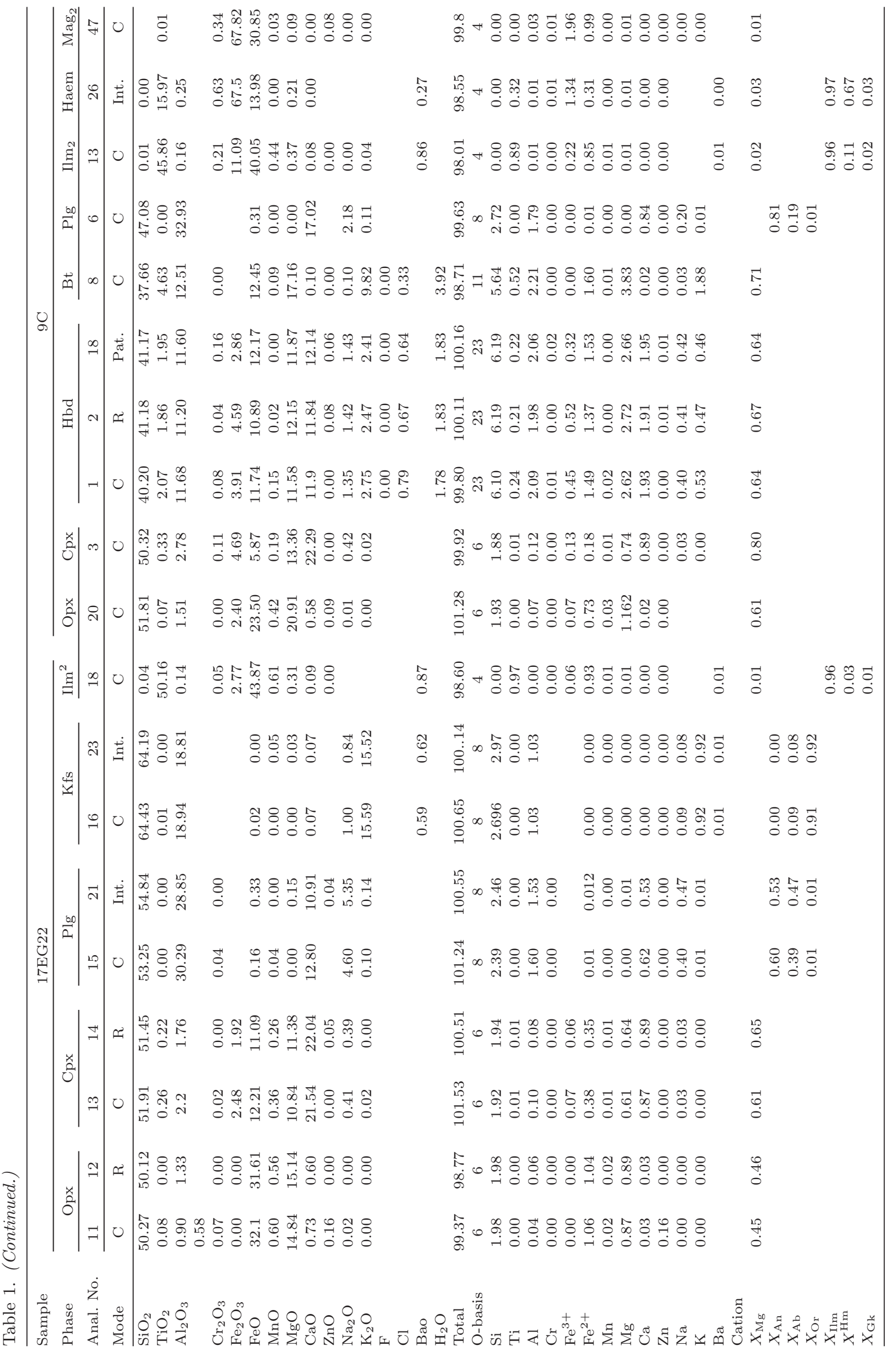



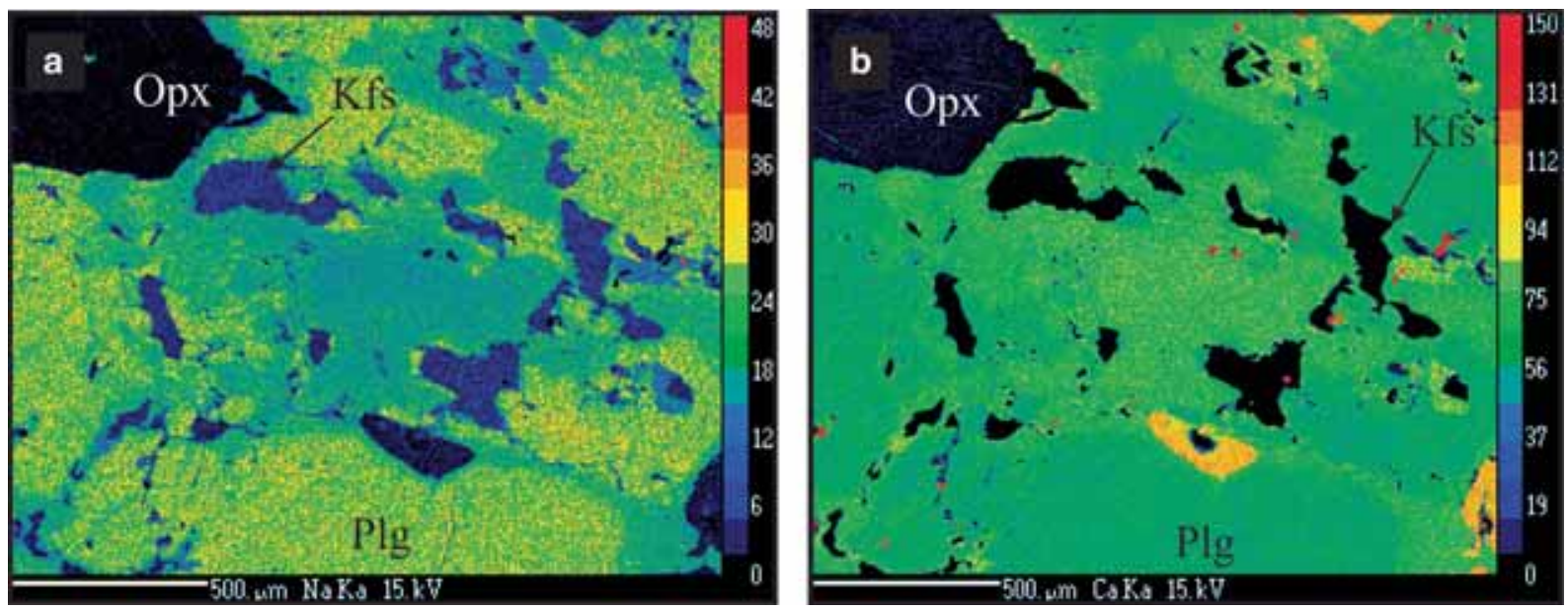

Figure 8. Element X-ray map of $\mathrm{Na}(\mathbf{a})$ and $\mathrm{Ca}(\mathbf{b})$ in patchy antiperthite. The maps show Na-loss and concomitant Ca-gain of plagioclase.

Table 2. EDS analytical data of pyrrhotite grains and calculated log $f S_{2}$ values from two samples of mafic granulite.

\begin{tabular}{lccccccrr}
\hline Sample & $\begin{array}{c}\text { No. of } \\
\text { analyses }\end{array}$ & $\mathrm{Fe}$ & $\mathrm{S}$ & Total & $X_{\mathrm{Fe}}$ & $X_{\mathrm{FeS}}$ & $\begin{array}{c}T \\
(\mathrm{C})\end{array}$ & $\begin{array}{c}T \\
(\mathrm{~K})\end{array}$ \\
\hline 17EG16 & 7 & 57.95 & 42.05 & 100 & 0.44 & 0.88 & 765 & 1038 \\
17EG14 & 5 & 57.54 & 42.46 & 100 & 0.44 & 0.88 & 733 & 1006 \\
\hline
\end{tabular}

ilmenite grains contain a negligible haematite component. Some samples of assemblage A contain bipartite grains of $\mathrm{Ilm}_{2}$ (both haematite-free and with haematite lamellae) and magnetite $\left(\operatorname{Mag}_{2}\right)$ (figure $4 \mathrm{~d}$ and e) in contact with orthopyroxene. $\mathrm{Mag}_{2}$ does not contain ilmenite lamellae and has a low $\mathrm{Ti}$ content $\left(\mathrm{TiO}_{2}<1\right.$ wt\%), which suggests that it contained a negligible ulvöspinel component. $\mathrm{Ilm}_{1}$ within clinopyroxene in 17EG16 is free of exsolved haematite, while those occurring within porphyroblastic hornblende (sample 9C) contain haematite lamellae. Phase chemical data show no significant compositional variation between $\mathrm{Ilm}_{1}$ and $\mathrm{Ilm}_{2}$. Therefore, it is likely that the ilmenite was inherited from lower grade assemblages. The occurrence of $\mathrm{Mag}_{2}$ and $\mathrm{Ilm}_{2}$ (with exsolved haematite) in contact with orthopyroxene can be explained by the following reactions which probably took place simultaneously:

$$
\begin{aligned}
& 6 \mathrm{FeSiO}_{3}+\mathrm{O}_{2}=2 \mathrm{Fe}_{3} \mathrm{O}_{4}+6 \mathrm{SiO}_{2}, \\
& \text { (in } \mathrm{Opx} \text { ) } \quad \mathrm{Mag}_{2} \quad \mathrm{Qtz} \\
& 4 \mathrm{FeSiO}_{3}+\mathrm{O}_{2}=2 \mathrm{Fe}_{2} \mathrm{O}_{3}+4 \mathrm{SiO}_{2} \text {. } \\
& \text { (in } \mathrm{Opx}) \quad \text { (in } \mathrm{Ilm}_{2} \text { ) Qtz }
\end{aligned}
$$

Reactions (1) and (2) occurred under oxidised conditions, which are indicated by the occurrence of fine-to-coarse exsolved lamellae (more than one sets) of haematite within ilmenite. This texture has been previously described from many regional granulite terranes (Harlov and Hansen 2005; Bose et al. 2009). Exsolution probably occurred at temperatures below $700^{\circ} \mathrm{C}$ across the $\mathrm{FeTiO}_{3}-\mathrm{Fe}_{2} \mathrm{O}_{3}$ join (Lindsley 1973, 1991; Ghiorso 1990; Burton 1991; Haggerty 1991). The occurrence of sulphide phases along with these oxide assemblages is noteworthy. Regarding samples in which $\mathrm{Mag}_{2}$ is absent and $\mathrm{Ilm}_{2}$ is haematite-poor $\left(X_{\mathrm{Haem}}^{\mathrm{Ilm}}=0.01-0.03\right.$ ), the latter phase is associated with Fe-rich orthopyroxene $\left(X_{\mathrm{Opx}}^{\mathrm{Fe}}=0.45-0.55\right.$, figure 9$)$ and pyrrhotite. The latter dominates over pyrite and chalcopyrite. In comparison, $\mathrm{Ilm}_{2}$ contains haematite component $\left(X_{\text {Haem }}^{\text {Ilm }}=0.09-0.11\right)$ in samples 17EG16 and $9 \mathrm{C}$ where $\mathrm{Mag}_{2}$ coexists with pyrite and orthopyroxene. In sample 17EG16, pyrrhorite is mostly abundant with chalcopyrite. Orthopyroxene is more magnesian in the sample $9 \mathrm{C}\left(X_{\mathrm{Mg}}^{\mathrm{Opx}}=0.62\right.$ $0.64)$ compared to the sample $17 \mathrm{EG} 16\left(X_{\mathrm{Mg}}^{\mathrm{Opx}}=\right.$ $0.54-0.57)$.

The occurrence of pyrrhotite and pyrite in association with the rhombohedral oxide phases depends on the oxidation condition as explained by Hall (1986, his figure 1) who showed that pyrite can coexist with magnetite at a relatively high $\mathrm{fO}_{2}$, whereas pyrrhotite coexists with magnetite at a lower $\mathrm{fO}_{2}$ condition. As described in the oxide-sulphide textures, pyrite $\left(\mathrm{Py}_{2}\right)$ with/without $\mathrm{Mag}_{3}$ grew marginally along the pyrrhotite grains 


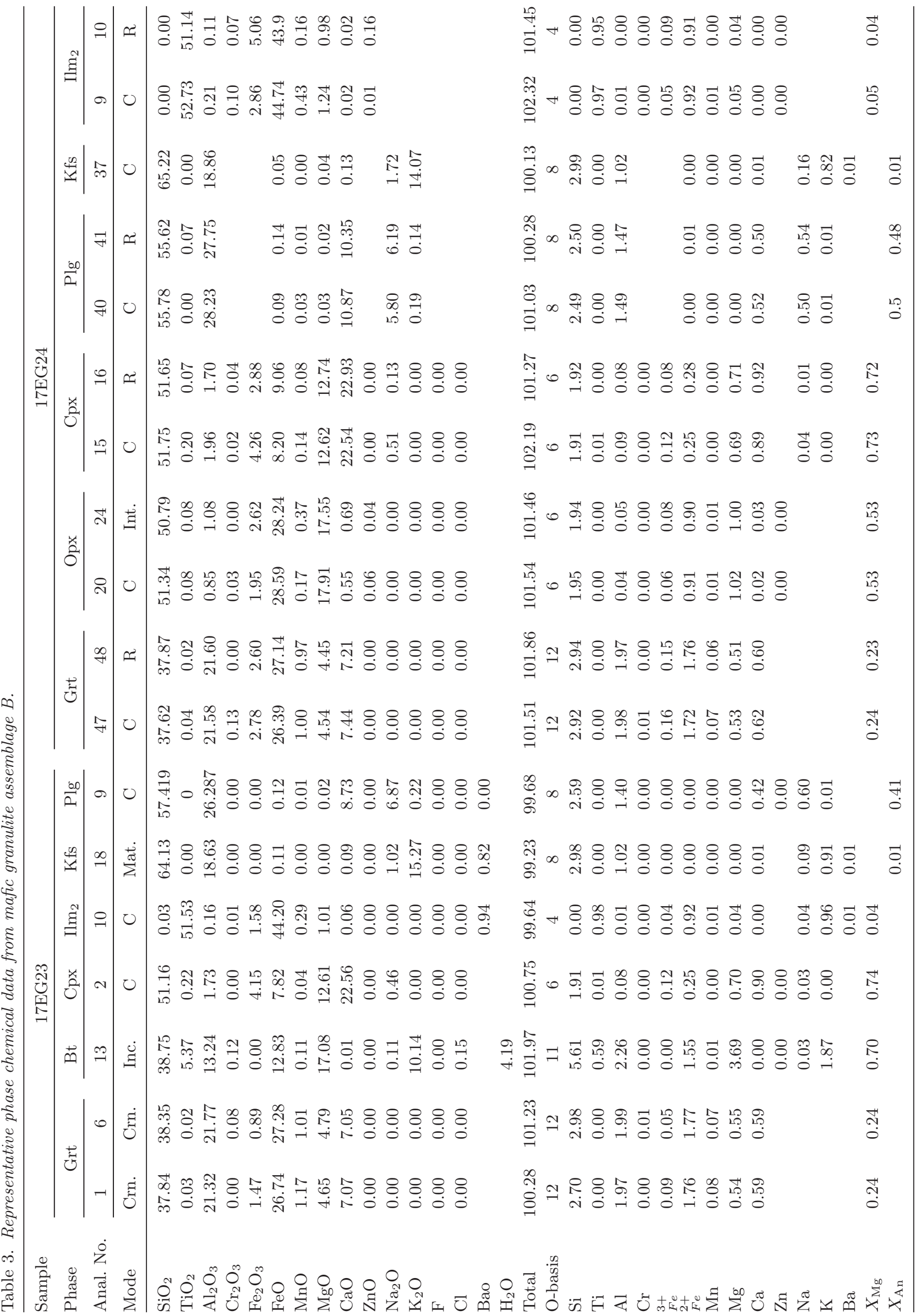



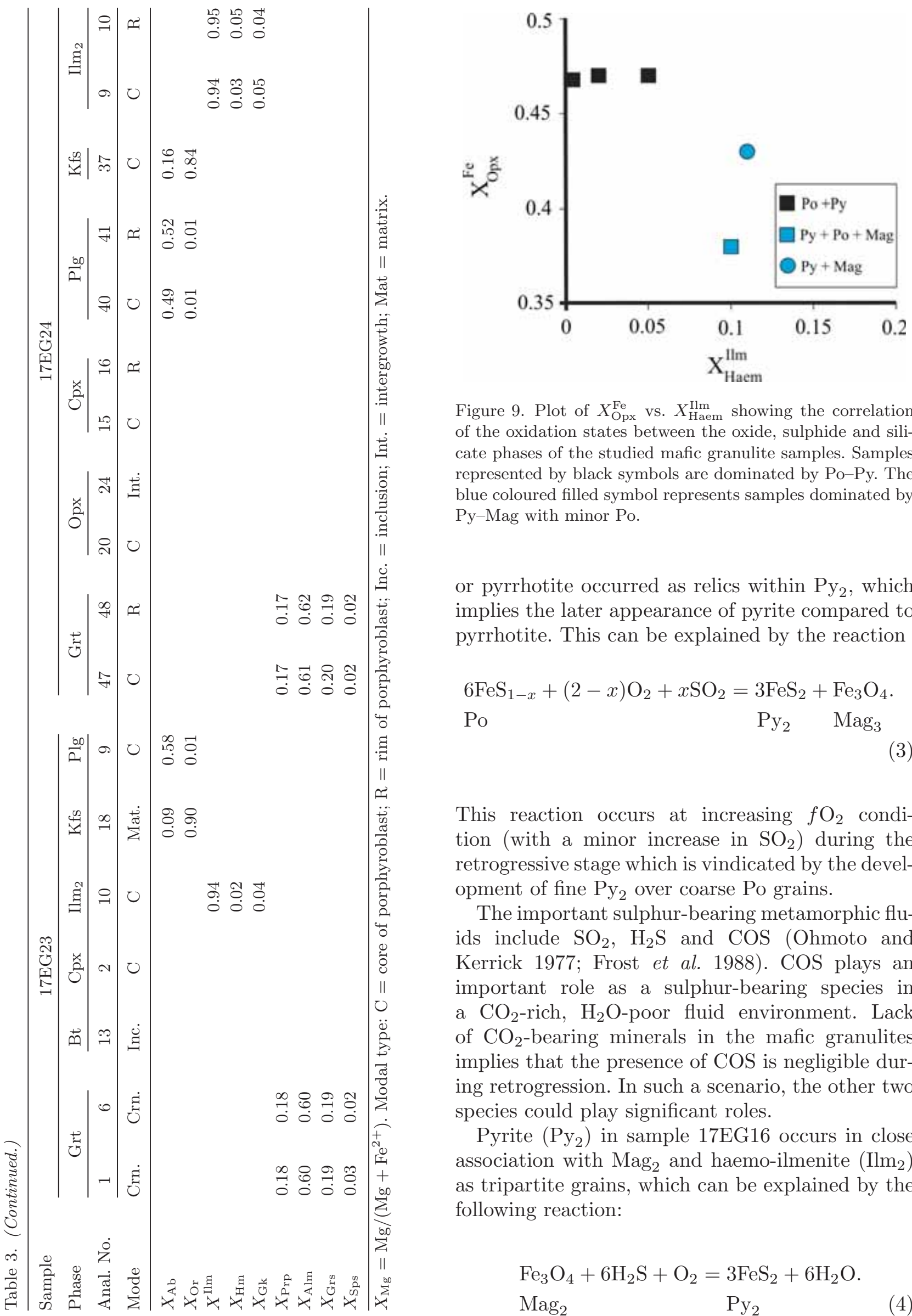

Figure 9. Plot of $X_{\mathrm{Opx}}^{\mathrm{Fe}}$ vs. $X_{\mathrm{Haem}}^{\mathrm{Ilm}}$ showing the correlation of the oxidation states between the oxide, sulphide and silicate phases of the studied mafic granulite samples. Samples represented by black symbols are dominated by Po-Py. The blue coloured filled symbol represents samples dominated by Py-Mag with minor Po.

or pyrrhotite occurred as relics within $\mathrm{Py}_{2}$, which implies the later appearance of pyrite compared to pyrrhotite. This can be explained by the reaction

$$
\begin{aligned}
& \underset{\mathrm{FeS}}{1-x}+(2-x) \mathrm{O}_{2}+x \mathrm{SO}_{2}=\underset{\mathrm{FeS}_{2}}{ }+\underset{\mathrm{Py}_{2}}{ }+\mathrm{Fe}_{3} \mathrm{O}_{4} . \\
& \mathrm{Mag}_{3}
\end{aligned}
$$

This reaction occurs at increasing $\mathrm{fO}_{2}$ condition (with a minor increase in $\mathrm{SO}_{2}$ ) during the retrogressive stage which is vindicated by the development of fine $\mathrm{Py}_{2}$ over coarse Po grains.

The important sulphur-bearing metamorphic fluids include $\mathrm{SO}_{2}, \mathrm{H}_{2} \mathrm{~S}$ and $\mathrm{COS}$ (Ohmoto and Kerrick 1977; Frost et al. 1988). COS plays an important role as a sulphur-bearing species in a $\mathrm{CO}_{2}$-rich, $\mathrm{H}_{2} \mathrm{O}$-poor fluid environment. Lack of $\mathrm{CO}_{2}$-bearing minerals in the mafic granulites implies that the presence of COS is negligible during retrogression. In such a scenario, the other two species could play significant roles.

Pyrite $\left(\mathrm{Py}_{2}\right)$ in sample 17EG16 occurs in close association with $\mathrm{Mag}_{2}$ and haemo-ilmenite $\left(\mathrm{Ilm}_{2}\right)$ as tripartite grains, which can be explained by the following reaction:

$$
\begin{gathered}
\mathrm{Fe}_{3} \mathrm{O}_{4}+6 \mathrm{H}_{2} \mathrm{~S}+\mathrm{O}_{2}= \\
\mathrm{Mag}_{2} \\
\mathrm{Py}_{2}
\end{gathered}
$$


In sample 9C (figure 6f), $\mathrm{Py}_{1}$ occurs within $\mathrm{Mag}_{3}$, which suggests a late stage oxidation reaction

$$
\begin{aligned}
3 \mathrm{FeS}_{2} & +8 \mathrm{O}_{2}= \\
\mathrm{Py}_{1} & \mathrm{Fe}_{3} \mathrm{O}_{4}
\end{aligned}+6 \mathrm{Sag}_{2} .
$$

Development of magnetite veins $\left(\mathrm{Mag}_{4}\right)$ along the intra-granular fractures often replaced by pyrite possibly occurs at this stage.

Chalcopyrite occurs as an intergrowth phase within pyrrhotite and pyrite. Experimental data of Yund and Kullerud (1966) show that a solid solution in the $\mathrm{Cu}-\mathrm{Fe}-\mathrm{S}$ system can be stable from $700^{\circ} \mathrm{C}$ down to $334^{\circ} \mathrm{C}$. Therefore, chalcopyrite possibly was in equilibrium with the other sulphide phases throughout the cooling history and exsolved at a much later stage.

The peak assemblage of the migmatitic variety in sample 17EG23 contains garnet in association with clinopyroxene, orthopyroxene, plagioclase, antiperthite, K-feldspar, quartz, ilmenite, pyrite and chalcopyrite with some minor amount of calcite. Similar assemblage is reported from many high-pressure granulites (O'Brien 2008; Racek et al. 2008). In sample 17EG24, garnet occurs as thick to thin rim surrounding plagioclase, orthopyroxene and clinopyroxene grains. Porphyroblastic garnet in sample 17EG23 shows stable grain contacts with orthopyroxene, plagioclase and clinopyroxene. Although there is no direct textural evidence for the appearance of garnet in the peak assemblage, we consider the breakdown of hornblende by the following reaction as the plausible reason:

$$
\begin{aligned}
& \text { Hornblende }+ \text { plagioclase } \\
& \quad=\text { garnet }+ \text { clinopyroxene }+ \text { melt } .
\end{aligned}
$$

Experimental data on hornblende dehydration melting show the stability of the restitic assemblage of garnet + clinopyroxene + quartz $+\mathrm{Fe}-\mathrm{Ti}$ oxide form at pressure $>10$ kbar (Skjerlie and PatinõDouce 1995) with tonalitic to trondhjemitic melt composition (Beard and Lofgren 1991; Rushmer 1991, 1993; Wolf and Wyllie 1994; Springer and Seck 1997). The presence of orthopyroxene in the assemblage presumably indicates pressure $<10$ kbar (Pattison 2003). The leucosome layers of the migmatitic mafic granulite samples possibly bear the evidence of melting, melt migration and local crystallisation. Textural features such as cuspate grain boundaries of quartz and thin film of
K-feldspar over plagioclase may further be considered as evidences of melt presence in the system (Sawyer 1999; Brown 2001).

The formation of garnet corona ( + quartz) surrounding orthopyroxene and clinopyroxene in 17EG24 suggests the reactions:

Orthopyroxene + plagioclase $=$ garnet + quartz

Clinopyroxene + plagioclase $=$ garnet + quartz.

These reactions have a moderately positive $\mathrm{d} P / \mathrm{d} T$ slope and may occur during cooling as well as loading. Given the incipient nature of reaction products (garnet corona), the former possibility looks more possible. The formation of garnet corona in migmatitic mafic granulite implies a lowering of temperature and pressure under $\mathrm{H}_{2} \mathrm{O}$ undersaturated condition when $\mathrm{H}_{2} \mathrm{O}$ was partitioned into the anatectic melt that was mostly lost from the system (Dziggel et al. 2012).

The late stage development of barite replacing pyrite grains in assemblage B must have occurred under much lower temperature conditions as evidenced by the filling of the brittle fracture in plagioclase grains. These partially healed fractures often crosscut the sulphide-sulphate grains. Barite crystallisation is usually favoured in a highly oxygenated condition. Carroll and Rutherford (1987) experimentally showed that the sulphate phases become stable when the $\mathrm{fO}_{2}$ condition reaches 2 units above the FMQ buffer. In the present case, ilmenite also contains a minor amount of $\mathrm{Ba}$ in both the assemblages. Thus, fluctuation of $\mathrm{fO}_{2}$ occurred over a wide range of post-peak metamorphic temperature in mafic granulite.

The development of patchy antiperthite in plagioclase indicates the formation of the latter by metasomatic fluid. The loss of $\mathrm{Na}$ and gain of $\mathrm{Ca}$ in plagioclase can occur in a $\mathrm{CaCl}_{2}$-dominated fluid through a reaction

$$
\begin{aligned}
& \mathrm{CaCl}_{2}(\mathrm{aq})+2 \mathrm{NaAlSi}_{3} \mathrm{O}_{8} \\
& \quad=2 \mathrm{NaCl}(\mathrm{aq})+\mathrm{CaAl}_{2} \mathrm{Si}_{2} \mathrm{O}_{8}+4 \mathrm{SiO}_{2} .
\end{aligned}
$$

This reaction has been experimentally constrained (Shmulovich and Graham 2004; Khodorevskaya and Aranovich 2016). The interaction of plagioclase with $\mathrm{CaCl}_{2}$ rich aqueous fluids during retrogression would shift this reaction to the right and subsequently enrich the aqueous fluid in $\mathrm{NaCl}$. 
Table 4. Geothermobarometric results from representative samples of mafic granulite.

\begin{tabular}{|c|c|c|c|c|}
\hline Sample no. & Thermo/barometer used & Model & Assumed $P / T$ & Results \\
\hline \multirow[t]{4}{*}{ 17EG14 } & Opx-Ilm thermometer & Bishop (1980) & $8.0 \mathrm{kbar}$ & $890^{\circ} \mathrm{C}$ \\
\hline & Cpx-Ilm thermometer & Bishop (1980) & $8.0 \mathrm{kbar}$ & $733^{\circ} \mathrm{C}$ \\
\hline & 2Pyroxene thermometer & Kretz (1982) & & $677^{\circ} \mathrm{C}$ \\
\hline & 2 Feldspar thermometer & Stormer and Whitney (1977) & $8.0 \mathrm{kbar}$ & $870^{\circ} \mathrm{C}$ \\
\hline \multirow[t]{2}{*}{ 17EG16 } & Opx-Ilm thermometer & Bishop (1980) & $8.0 \mathrm{kbar}$ & $778^{\circ} \mathrm{C}$ \\
\hline & 2Pyroxene thermometer & Kretz (1982) & & $686^{\circ} \mathrm{C}$ \\
\hline \multirow[t]{3}{*}{$9 \mathrm{C}$} & Al-in-hornblende barometers & Anderson and Smith (1995) & $600^{\circ} \mathrm{C}$ & $7.15 \mathrm{kbar}$ \\
\hline & Cpx-Ilm thermometer & Bishop (1980) & $8.0 \mathrm{kbar}$ & $536^{\circ} \mathrm{C}$ \\
\hline & Opx-Ilm thermometer & Bishop (1980) & $8.0 \mathrm{kbar}$ & $612^{\circ} \mathrm{C}$ \\
\hline \multirow[t]{4}{*}{ 17EG22 } & Opx-Ilm thermometer & Bishop (1980) & $8.0 \mathrm{kbar}$ & $785^{\circ} \mathrm{C}$ \\
\hline & Cpx-Ilm thermometer & Bishop (1980) & $8.0 \mathrm{kbar}$ & $609^{\circ} \mathrm{C}$ \\
\hline & 2Pyroxene thermometer & Kretz (1982) & & $704^{\circ} \mathrm{C}$ \\
\hline & 2 Feldspar thermometer & Stormer and Whitney (1977) & $8.0 \mathrm{kbar}$ & $892^{\circ} \mathrm{C}$ \\
\hline \multirow[t]{3}{*}{ 17EG23 } & Gt-Cpx geothermometer & Ganguly (1979) & $8.0 \mathrm{kbar}$ & $750^{\circ} \mathrm{C}$ \\
\hline & Cpx-Ilm thermometer & Bishop (1980) & $8.0 \mathrm{kbar}$ & $773^{\circ} \mathrm{C}$ \\
\hline & GCPS (Di- barometer) & Moecher et al. (1988) & $780^{\circ} \mathrm{C}$ & $7.5 \mathrm{kbar}$ \\
\hline \multirow[t]{6}{*}{ 17EG24 } & Gt-Opx geothermometer & Lee and Ganguly (1988) & $8.0 \mathrm{kbar}$ & $741^{\circ} \mathrm{C}$ \\
\hline & GOPQ, RCLC & Pattison (2003) & $7.97 \mathrm{kbar}$ & $672^{\circ} \mathrm{C}$ \\
\hline & Gt-Cpx thermometer & Ganguly (1979) & $8.0 \mathrm{kbar}$ & $780^{\circ} \mathrm{C}$ \\
\hline & Gt-Ilm thermometer & Pownceby et al. (1987) & & $545^{\circ} \mathrm{C}$ \\
\hline & Cpx-Ilm thermometer & Bishop (1980) & $8.0 \mathrm{kbar}$ & $726^{\circ} \mathrm{C}$ \\
\hline & GCPS (di-barometer) & Moecher et al. (1988) & $765^{\circ} \mathrm{C}$ & $7.8 \mathrm{kbar}$ \\
\hline
\end{tabular}

\section{Geothermobarometry}

Estimation of $P-T$ condition of metamorphism in a polymetamorphosed UHT terrane is always problematic, particularly for mafic granulites (Huang et al. 2018). A major problem is related to lower temperature reequlibration of mineral composition (Frost and Chacko 1989; Harley 1989; Pattison et al. 2003). Lack of garnet in mafic granulite assemblage A restricts us from using common geothermobarometers. Peak metamorphic temperature was estimated from fossil thermometers using the reintegrated composition of peak phases. The two-feldspar thermometer of Stormer and Whitney (1977) gives a temperature estimation close to $870^{\circ} \mathrm{C}$ in sample $17 \mathrm{EG} 14$. The orthopyroxeneilmenite thermometer of the same assemblage yields a temperature $\sim 890^{\circ} \mathrm{C}$. The two-pyroxene model of Kretz (1982) yields lower temperatures (table 4). On the other hand, sample 17EG16 yields a maximum temperature of $780^{\circ} \mathrm{C}$ using the orthopyroxene-ilmenite thermometer of Bishop (1980).

Sample $9 \mathrm{C}$ contains hornblende as an additional phase within the assemblage. The aluminiumin hornblende barometer of Anderson and Smith (1995) yields $\sim 7$ kbar pressure. The orthopyroxeneilmenite thermometer yields $600^{\circ} \mathrm{C}$ for the same sample.
In sample 17EG22, patches of K-feldspar within plagioclase give a temperature close to $890^{\circ} \mathrm{C}$ estimated from a two feldspar thermometer proposed by Stormer and Whitney (1977). The two-pyroxene thermometer yields a maximum temperature of $\sim 700^{\circ} \mathrm{C}$, while the orthopyroxene-ilmenite thermometer yields a temperature $\sim 785^{\circ} \mathrm{C}$.

The $P-T$ condition has been also constrained from type B migmatitic mafic granulite in 17EG23 and 17EG24 samples. The assemblage garnetclinopyroxene-plagioclase-quartz in the 17EG23 sample yields a pressure of $\sim 7.5$ kbar using the model of Moecher et al. (1988). The orthopyroxeneilmenite thermometer gives $\sim 780^{\circ} \mathrm{C}$ temperature. In the same sample, the garnet-clinopyroxene thermometer gives $\sim 750^{\circ} \mathrm{C}$ temperature using the model of Ganguly (1979), while the clinopyroxeneilmenite thermometer of Bishop (1980) gives a temperature $\sim 775^{\circ} \mathrm{C}$. In sample $17 \mathrm{EG} 24$, the garnetorthopyroxene thermometer of Lee and Ganguly (1988) gives the maximum temperature of $\sim 740^{\circ} \mathrm{C}$ while the GOPQ barometer of Pattison et al. (2003) gives pressure estimates 7.7-7.9 kbar. Temperature was also calculated for the garnet-clinopy roxene using the model of Ganguly (1979) which yields a maximum temperature of $830^{\circ} \mathrm{C}$, greater than the garnet-orthopyroxene temperature estimate. 
Table 5. Oxygen fugacity values calculated at estimated pressure and temperature (QUILF reactions are after Andersen et al. 1993).

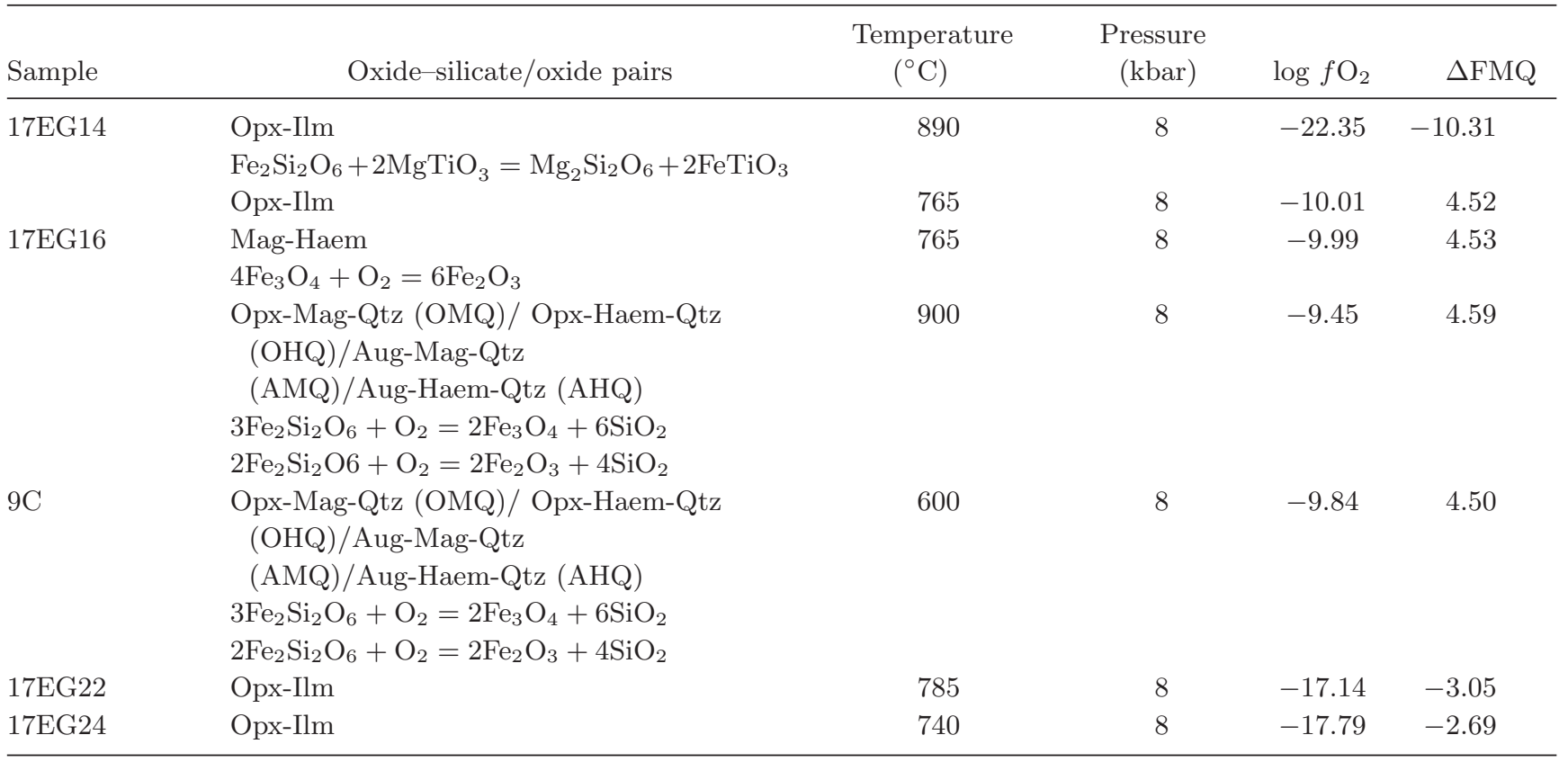

\section{Oxygen fugacity}

Oxygen fugacity was calculated using the QUILF programme (Andersen et al. 1993) using suitable oxide-silicate and oxide-oxide mineral pairs in samples from both the assemblages (table 5). Mafic granulite samples having assemblage A show similar mineralogy (albeit some minor variation in oxide-sulphide assemblages) and reflect an end product of the same metamorphic cycle, even though temperature and pressure calculated from both assemblages show minor differences. To avoid uncertainty in calculation, we chose to take exact temperature values constrained from each sample. The pressure value for each sample has been fixed at 8 kbar considering the present estimates and published $P-T$ records (Dasgupta et al. 1993; Bose et al. 2000, 2003).

The $f \mathrm{O}_{2}$ value was calculated from the reactions involving the coexisting orthopyroxene-ilmenite, magnetite-haematite and orthopyroxene-magnetite-quartz:

$$
\begin{aligned}
& \mathrm{Fe}_{2} \mathrm{Si}_{2} \mathrm{O}_{6}+2 \mathrm{MgTiO}_{3} \\
& \quad=\mathrm{Mg}_{2} \mathrm{Si}_{2} \mathrm{O}_{6},+2 \mathrm{FeTiO}_{3}, \\
& 4 \mathrm{Fe}_{3} \mathrm{O}_{4}+\mathrm{O}_{2}=6 \mathrm{Fe}_{2} \mathrm{O}_{3} \\
& \mathrm{FeSiO}_{3}+\mathrm{O}_{2}=2 \mathrm{Fe}_{3} \mathrm{O}_{4}+6 \mathrm{SiO}_{2} .
\end{aligned}
$$

Oxygen fugacity values calculated from all these reactions are 3-4 log units higher than the FMQ

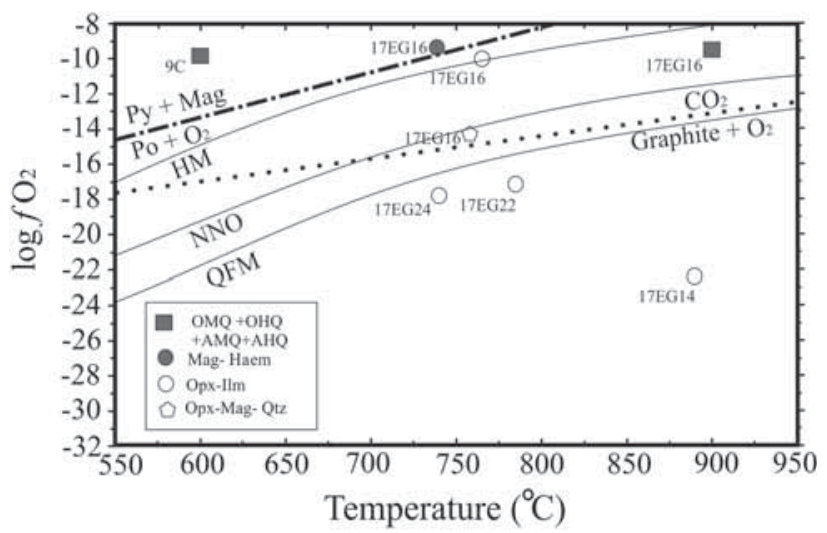

Figure 10. Plot of temperature vs. oxygen fugacities of the mafic granulite samples at 8 kbar. The positions of HM, NNO, CCO and QFM buffers are drawn for comparison and reference. Abbreviations used for assemblages: OMQ, orthopyroxene-magnetite-quartz; OHQ, orthopyroxene-haematite-quartz; AMQ, augite-magnetitequartz; AHQ, augite-haematite--quartz.

equilibrium for samples $9 \mathrm{C}$ and 17EG16. For samples 17EG14, 17EG22 and 17EG24, oxygen fugacity values were calculated by only using reaction (10). From other reactions, the $\mathrm{fO}_{2}$ values could not be ascertained due to the absence of discrete magnetite grain within the assemblage.

Equilibrium reaction (11) has been used to calculate $\mathrm{fO}_{2}$ values for 17EG16 which show a high $\mathrm{fO}_{2}$ value (figure 10), except for one value for 17EG16 calculated from reaction (12), which 
shows a fugacity value close to the graphite stability curve. On the other hand, a fugacity value was estimated from reaction (10) for 17EG14 samples which show significantly low oxygen fugacity values below the graphite stability curve. The absence of any discrete magnetite grains and presence of exsolution-free ilmenite in the mineral assemblage yield low oxygen fugacity values which need clarification. Fugacity values calculated from samples 17EG22 and 17EG24 also yield log $\mathrm{fO}_{2}$ values below the FMQ buffer. The pyritepyrrhotite buffer curve (reaction (12)) in figure 10 vindicates our textural observation. Both samples $9 \mathrm{C}$ and 17EG16 show the dominance of pyrite over pyrrhotite, but pyrite $\left(\mathrm{Py}_{2}\right)$ and magnetite $\left(\mathrm{Mag}_{3}\right)$ replace pyrrhotite in the latter sample. As pyrrhotite is stable in a comparatively reduced condition, there must be a decrease in oxygen fugacity during the peak stage. The rocks experienced higher oxygen fugacity during retrogression, which promoted the formation of $\mathrm{Py}_{2}$ and $\mathrm{Mag}_{3}$ replacing the pyrrhotite. All the other samples have low oxygen fugacity below the FMQ buffer but show textural evidence in favour of an increase in oxygen fugacity, except for sample 17EG14 (figure 10).

\section{Discussion}

\subsection{Petrological evolution of mafic granulites of the $E G B$}

Mafic granulite is an important member of many regional granulite rock suites and preserves information about the interaction between the lower crust and the sub-lithospheric mantle (Harley 1989). This rock occurs either as a dismembered mafic intrusive that later underwent high-grade metamorphism and recrystallisation (Harley 1989; Montanini and Tribuzio 2001; Faryad and Hoinkes 2004) or as a basic rock metamorphosed by dehydration melting (Beard and Lofgren 1991; Pattison 1991; PatiñoDouce and Beard 1995; Springer and Seck 1997). For the latter, mafic granulite usually occurs as enclaves within felsic components of the granulite suite without intrusive contact. Two different types of mafic granulites have been studied in the present work. The massive variety of mafic granulite is reported from many localities of the EGB where it has been established that this rock has a mafic magmatic protolith which was emplaced at a deep crustal level before being metamorphosed to UHT condition
(Dasgupta et al. 1993; Sengupta et al. 1996; Bose et al. 2003; Bhui et al. 2007). A similar evolutionary history is invoked in the present massive variety of mafic granulite. Geochronological data of Shaw et al. (1997) from the Rayagada area of the EGB suggest ca. $1450 \mathrm{Ma}$ emplacement age of mafic magma within the lower crust. Kelsey et al. (2017) studied the mafic granulite of the Anakapalle locality of the EGB and reported that the mafic magma was emplaced at ca. 1580 Ma. Recent tectonic modelling of EGB indicates that the UHT metamorphism of the Eastern Ghats Province (including the Domain 2 of EGB) took place in an accretionary tectonic setting where rifting occurred with the opening of the back arc basin during ca. 1480-1250 Ma (Dasgupta et al. 2013, 2017; Bose and Dasgupta 2018). The sediments that were deposited within the back arc basin along with the mafic and alkaline magma (emplaced at ca. 1.48-1.30 Ga, Upadhyay 2008; Ranjan et al. 2018) suffered UHT metamorphism along an anticlockwise path during 1130-990 Ma (Bose et al. 2011; Das et al. 2011; Korhonen et al. 2013b). Such an anticlockwise path could be a manifestation of intense magmatic activity after or during tectonic crustal thinning (magmatic intraor under-plating), which is a characteristic of a magmatic arc (Abati et al. 2003).

The occurrence of migmatitic mafic granulite is rare in the EGB and its evolutionary history is thus less constrained. The origin of the migmatitic variety is related to anatexis of mafic protolith as reported from many regional metamorphic terranes (Brown 1994; Hartel and Pattison 1996; Jones and Escher 2002; Padrón-navarta et al. 2008; Gross et al. 2009; Dziggel et al. 2012; Feisel et al. 2018). Experimental data show that mafic protolith undergoes melting at a temperature above $800^{\circ} \mathrm{C}$, but a tangible percentage $(>10 \%)$ of melt is generated at $>850^{\circ} \mathrm{C}$ in the pressure range of 5-10 kbar (Beard and Lofgren 1991; Rapp et al. 1991; Rushmer 1991; Sen and Dunn 1994; Wolf and Wyllie 1994; PatiñoDouce and Beard 1995; Rapp and Watson 1995; López and Castro 2001). A general observation of all the experimental results is that the produced melt has a tonalitictrondhjemite composition, whereas the solid residue assemblage is represented by orthopyroxene + clinopyroxene + plagioclase with or without garnet. A crucial textural evidence for anatectic mafic migmatite is the presence of relic hornblende within garnet (Hartel and Pattison 1996). Unfortunately, we could not find any relic hornblende within 
porphyroblastic garnet and thus direct textural evidence for anatexis of mafic protolith could not be provided. One possibility is that the peritectic melting reaction consuming hornblende overstepped in the realm of UHT metamorphism without leaving any relic. On the other hand, textural evidences like thin K-feldspar film on plagioclase and quartz support onset of melting. Conventional thermobarometric data suggest a peak metamorphic temperature of $\sim 890^{\circ} \mathrm{C}$ at $8 \mathrm{kbar}$ pressure, but this must be a reset value as similar mafic granulites from the nearby localities yield higher temperature estimates (Dasgupta et al. 1991, 1993; Bose et al. 2003). It is also important to mention that the aluminous granulites of the same suite of rocks preserve textural and compositional evidence of UHT metamorphism (Sengupta et al. 1990; Bose et al. 2000, 2006; Das et al. 2011; Korhonen et al. 2013a). Moreover, the presence of orthopyroxene lamellae within clinopyroxene in the studied samples provides fossil evidence of UHT metamorphism (Frost and Chacko 1989; Harley 2008).

\subsection{Fluid evolution at the lower crust}

An attempt has been done in this study to understand the fluid-rock interaction in lower crustal condition using the texture and mineralogy of the oxide-sulphide-silicate mineral assemblages. The textural study of both the varieties of mafic granulite suggests the stability of clinopyroxene + orthopyroxene + plagioclase + ilmenite \pm garnet \pm magnetite \pm pyrrhotite, chalcopyrite, \pm pyrite $\left(\mathrm{Py}_{1}\right)$ at the peak metamorphic condition. Oxide mineralogy at the peak stage is dominated by ilmenite $\left(\operatorname{Ilm}_{2}\right)$ with/without discrete magnetite. When occurring adjacent to ilmenite, magnetite does not contain exsolved ilmenite, and thus unmixing from an oxide solid solution (Vincent and Phillips 1954) is not a feasible mechanism for the formation of the two-oxide aggregate. On the contrary, the intimate association of discrete magnetite $\left(\mathrm{Mag}_{2}\right)$ with $\mathrm{Ilm}_{2}$ possibly implies that the former stabilised in the oxidised samples through reaction (1). There is no discrete haematite grain in any of the assemblages, which implies that the $\mathrm{fO}_{2}$ condition never reached the HM buffer during the metamorphic evolution. In sample 9C, haemo-ilmenite $\left(\mathrm{Ilm}_{2}\right)$ coexists with $\mathrm{Mag}_{2}$ in the matrix in a more oxidised assemblage, indicating fluctuations of the $\mathrm{fO}_{2}$ condition for different samples, and the fluid composition was mostly buffered by mineral assemblages. In a multicomponent fluid, such fluctuation of $\mathrm{fO}_{2}$ should be dependent on fugacities of other components. Based on the composition of the pyrrhotite and calculated sulphide phase relationships (Toulmin and Barton 1964), the estimated value of $f \mathrm{~S}_{2}$ varies in the range of -3.50 to -3.67 at the appropriate temperature conditions (table 2).

Sulphide phases are dominated either by pyrite (samples 17EG16 and 9C) or pyrrhotite (samples 17EG14, 17EG22, 17EG23 and 17EG24). Temperature vs. $\mathrm{fO}_{2}$ plot using QUILF equilibria (Andersen et al. 1993) suggests lower $\mathrm{fO}_{2}$ values for pyrrhotite-bearing assemblages compared to the pyrite-bearing ones. Experimental data suggest that the stability of sulphide phases in mafic rock depends on $\mathrm{fO}_{2}$ conditions at temperature $>743^{\circ} \mathrm{C}$, above which pyrrhotite becomes stable over pyrite irrespective of $\mathrm{fO}_{2}$ values (Kullerud 1957). Therefore, pyrrhotite should occur as the stable phase at the UHT metamorphic peak in both the assemblages while pyrite (both $\mathrm{Py}_{1}$ and $\mathrm{Py}_{2}$ ) must have formed at a temperature lower than the metamorphic peak. The calculated $f_{2}$ values of samples with pyrite-dominated assemblages are 3$4 \mathrm{log}$ units higher than the FMQ buffer. Another important feature is the development of $\mathrm{Py}_{2}$ and $\mathrm{Mag}_{3}$ at the retrograde stage of metamorphism that presumably was augmented by cooling at high $\mathrm{fO}_{2}$ condition.

A sustained high oxygen fugacity in the lower crust can be achieved in several ways:

(1) High $\mathrm{fO}_{2}$ mineral assemblages in the lower crust can be inherited from an oxidised protolith (e.g., Arima et al. (1986) for metapelitic granulite). Considering that the protolith of the massive variety of mafic granulite is basic magma, we explore the possibility of inheriting highly oxidised mineral assemblage. In the lower crustal condition, $f \mathrm{O}_{2}$ conditions of basic magma are controlled by mechanisms like partial melting and melt segregation (Ballhaus 1993; Zhang et al. 2013). Phase relations in the $\mathrm{FeO}-\mathrm{Fe}_{2} \mathrm{O}_{3}$ system show that magnetite can be a stable mineral with haematite up to $\sim 1530^{\circ} \mathrm{C}$ with increasing $\mathrm{fO}_{2}$ (Darken and Gurry 1945; Muan 1958). Experimental data suggest that basic magma in arc settings is more oxidised compared to other tectonic settings (Carmichael 1991; Ballhaus 1993). Geochemical characterisation of mafic magmatism in EGB is poorly constrained and available 
data suggest an extensional setting (Sengupta et al. 1996) possibly during ca. 1580-1350 Ma (Shaw et al. 1997; Kelsey et al. 2017; Ranjan et al. 2018). On the other hand, metamorphic and geochronological histories suggest a prolonged subduction-accretion history of the EGB during ca. 1.2-0.9 Ga (Dasgupta et al. 2013, 2017; Bose and Dasgupta 2018). This time frame witnessed high temperature metamorphism, deformation and emplacement of granitoids of suspected arc signatures (Saha and Karmakar 2015). It is likely that the mafic granulites of Domain 2 of EGB could be chemically modified by arc magmas. Some of the rhombohedral oxides thus could be inherited from a magmatic source. This possibility could not be further explored in the absence of precision geochemical data.

(2) The other possibility for high $f_{2}$ in lower crustal rocks is the internal fluid buffering. The high oxidation states of the mineral in samples 17EG16 and 9C could only reflect an oxidised protolith with internal buffering of oxygen during metamorphism. This is probably the most dominant process for the present samples. On the other hand, features like $\mathrm{Mag}_{4}$ veins, rims of $\mathrm{Py}_{2}$ on $\mathrm{Po}$ and alteration textures are likely to be formed at a later stage by an external fluid source.

(3) The third possibility is the external fluid source. Oxidation by an infiltrating fluid during granulite facies metamorphism was not clearly understood for a long time. Although $\mathrm{CO}_{2}$ and $\mathrm{H}_{2} \mathrm{O}$ are not much effective as oxidising agents in graphite-free rocks (Frost 1991), the $\mathrm{SO}_{2}$ component in brine could be an important oxidising agent (Crawford and Hollister 1986; Stout et al. 1986; Cameron and Hattori 1994; Harlov et al. 1997; Newton and Manning 2005; Harlov 2012). In a subduction-accretion setting, fluid comes from the dehydration of the hot subduction zone and is dominated by $\mathrm{H}_{2} \mathrm{O}$ with solutes of $\mathrm{Ca}$ and $\mathrm{Al}$ (Manning 2004; Zheng et al. 2016). This hydrothermal supercritical fluid acts as an ideal agent for material transport (including sulphates) owing to the alkali chloride components in it (Keppler 1996; Ni et al. 2017; Barnes et al. 2018). In such a halogen-enriched aqueous fluid, ion pair formation $\left(\mathrm{NaCl}_{\mathrm{aq}}-\mathrm{KCl}_{\mathrm{aq}}\right)$ is favoured at higher temperature and $\mathrm{Ca}$ shows strong mobility (Barnes et al. 2018). Other sources of concentrated brines could be deeply buried evaporates (Yardley and Graham 2002) or downward circulating dissolved salts of surficial origin in thermally excited convection cells (McLelland et al. 2002). Despite this, direct evidence of brine-rich fluid inclusions from lower crustal rocks is rare (Touret and Huizenga 2012; Touret and Nijland 2013), possibly due to their wetting behaviour with mineral phases (Touret 1985; Watson and Brenan 1987; Manning and Aranovich 2014).

Fluid inclusion data from the EGB (Chilka Lake by Bose et al. (2016); Simliguda by Bose et al. (2009); G. Madugula by Mohan et al. (2003); Vizianagaram by Sarkar et al. (2003)) show evidence of $\mathrm{CO}_{2}-\mathrm{H}_{2} \mathrm{O}$ fluid species without any direct evidence for brine. Interestingly, the high $\mathrm{F}$ contents in fluor-biotite (>3 wt\%; Bose et al. 2005; Ganguly et al. 2017) and fluor-wagnerite (>6 wt\% F; Das et al. 2017) in mineral assemblages indicate the possible association of halogen-rich fluid species during peak and retrograde metamorphic stages. For the granitic rocks, the composition of brine is dominated by $\mathrm{NaCl}$, whereas $\mathrm{CaCl}_{2}$ dominates in mafic rocks (Möller et al. 1997; Stober and Bucher 2005). In the present samples, the development of $\mathrm{Ca}-\mathrm{Na}$ patchy zoning in plagioclase possibly indicates the formation of the latter by a brine-rich fluid interaction (Harlov 2012). In addition to that, extensive veining of magnetite across the oxide-sulphide grains and myrmekite development along the boundary between perthitic K-feldspar and plagioclase possibly resulted from metasomatism by brine-rich fluid (Harlov et al. 2006; Touret 2009; Harlov 2012). Harlov and Hansen (2005) made a systematic study in Tamil Nadu, South India and proposed that the trend of oxide-silicate-sulphide mineral assemblages, composition and textures is the result of infiltrating brine $(\mathrm{NaCl}-\mathrm{KCl}$ containing oxidising component $\mathrm{CaSO}_{4}$ ) during high-grade metamorphism. Therefore, the high oxidation state in the rocks during retrogression could have occurred due to infiltration of a similar fluid. From the nearby area, Bose et al. (2009) showed that the UHT granulite metamorphism occurred at a high $\mathrm{fO}_{2}$ condition (3-4 $\log$ unit above the FMQ buffer) and subsequent infiltration of a separate fluid phase $\mathrm{CO}_{2}-\mathrm{H}_{2} \mathrm{O}$ (evident from the fluid inclusion data). They also argued that the post-peak metamorphic fluid was richer in brine concentration compared to the prepeak fluid. 


\subsection{Fluid evolution in shallow crustal level}

The migmatitic variety of mafic granulite contains barite along the brittle fractures, often replacing the sulphide and oxide phases and also found in association with calcite within the inter-granular space. Experiments on anhydrite show that stability of sulphate is favoured only when the $f \mathrm{O}_{2}$ is 2 log units above FMQ (Carroll and Rutherford 1987; Török et al. 2003). Experimental data suggest that barite precipitates at a shallow $\left(<400^{\circ} \mathrm{C}\right.$, 2 kbar) crustal condition under a high oxygenated condition (Hanor 1994, 2000; Yardley 2005). Since externally derived hydrothermal fluids could be responsible for oxidation and subsequently favoured barite precipitation (Ohmoto and Skinner 1983; Shikazono et al. 1983; Van Cranendonk and Pirajno 2004), infiltration of such a fluid possibly caused precipitation of barite along the brittle fractures of the migmatitic mafic granulite. In such a case, mixing of hot deep crustal fluid with cooler surficial hypersaline brine may cause leaching of sulphide minerals to release oxygen (Valenza et al. 2000). An increase in oxygen fugacity at the shallow level can also be caused by bacterial activity (Hattori and Cameron 1986).

The other possible external sources are connate fluid or remobilised meta-evaporites in shallow crustal condition (Hanor 2000). Shallow crustal brine may also arise from dissolution of halite followed by evaporation and precipitation (Rittenhouse 1967). However, fluid inclusion studies of a low temperature ore field suggest that relative to evaporites, bittern brines are more common in the subsurface geologic column (Yardley 2009).

\section{Conclusion}

From the field petrographic, geothermobarometric and calculated fluid data, we conclude that:

(1) The two varieties of mafic granulites evolved in two different processes. While the massive type mafic granulite represents metamorphosed deep-crustal basic magma, the migmatitic type underwent anatexis of the middle crust of basic composition. Both the varieties are now occurring as enclaves within charnockite gneiss.

(2) The calculated peak temperature is $890^{\circ} \mathrm{C}$, which is a reset value considering the UHT metamorphic history of the associated aluminous granulites.
(3) The occurrence of magnetite-ilmenite and pyrite-pyrrhotite in different textural modes indicates fluctuations of the $\mathrm{fO}_{2}$ condition during metamorphism, although the calculated values are always high with respect to the QFM buffer. The absence of haematite discrete grain indicates that the $\mathrm{fO}_{2}$ conditions never reached the HM buffer.

(4) A consistently high $\mathrm{fO}_{2}$ condition throughout the metamorphic history of the mafic granulite closely matches that of the aluminous granulite. We argue that infiltration of the Ca-rich brine solution could be responsible for elevating both the $f \mathrm{O}_{2}$ conditions and metasomatism of the lower crust. Fluid inclusion data from the nearby localities do not reveal the presence of brine fluid, which may be explained by the high wetting capacity of brine.

\section{Acknowledgements}

We acknowledge the financial support from the Council of Scientific and Industrial Research (CSIR), Government of India (Grant No. 24(0333)/ 14/EMR-II). Constructive review comments from Prof. Somnath Dasgupta helped us improve the quality of the paper. We thank Proloy Ganguly for his help during EPMA work. S B acknowledges infrastructural support from UGC-CAS and DST-FIST facilities extended to the Department of Geology, Presidency University. The efficient editorial handling by Prof Pulak Sengupta is greatly appreciated.

\section{References}

Abati J, Arenas R, Catalan J R M and Garcia F D 2003 Anticlockwise $\mathrm{P}-\mathrm{T}$ path of granulites from the Monte Castelo gabbro (Ordenes Complex, NW Spain); J. Petrol. 44 305-327.

Anderson J L and Smith D R 1995 The effects of temperature and $\mathrm{fO}_{2}$ on the Al-in-hornblende barometer; Am. Mineral. 80 549-559.

Andersen D J, Lindsley D H and Davidson P M 1993 QUILF: A pascal program to assess equilibria among Fe-Mg-MnTi oxides, pyroxenes, olivine, and quartz; Comput. Geosci. $191333-1350$.

Arima M, Kerrich R and Thomas A 1986 Sapphirinebearing paragneiss from the northern Grenville Province in Labrador, Canada. Protolith compositions and metamorphic P-T conditions; Geology 14 884-887. 
Ballhaus C 1993 Redox states of lithospheric and asthenospheric upper mantle; Contrib. Mineral. Petrol. 114 $331-348$

Barnes J D, Manning C E, Scambelluri M and Selverstone J 2018 The behavior of halogens during subduction-zone processes; In: The role of halogens in terrestrial and extraterrestrial geochemical processes: Surface, crust, and mantle (eds) Harlov D E and Aranovich L, Springer, Berlin, Geochemistry Chapter, Vol. 8, pp. 545-590, https://doi.org/10.1007/978-3-319-61667-4_8.

Beard J S and Lofgren G E 1991 Dehydration melting and water-saturated melting of basaltic and andesitic greenstones and amphibolites at 1, 3, and 6. 9 kbar; J. Petrol. 32 365-401.

Bhui U K, Sengupta P and Sengupta P 2007 Phase relations in mafic dykes and their host rocks from Kondapalle, Andhra Pradesh, India: Implications for the time-depth trajectory of the Palaeoproterozoic (late Archaean?) granulites from southern Eastern Ghats belt; Precamb. Res. $156153-174$.

Bishop F C 1980 The distribution of $\mathrm{Fe}^{2+}$ and $\mathrm{Mg}$ between coexisting ilmenite and pyroxene with applications to geothermometry; Am. J. Sci. 280 46-77.

Bohlen S R and Essene E J 1977 Feldspar and oxide thermometry of granulites in the Adirondack Highlands; Contrib. Mineral. Petrol. 62 153-169.

Bose S and Das K 2007 Sapphirine + quartz assemblage in contrasting textural modes from the Eastern Ghats belt, India: Implications for stability relations in UHT metamorphism and retrograde processes; Gondwana Res. 11 492-503.

Bose S and Dasgupta S 2018 Eastern Ghats belt, Grenvillianage tectonics and the evolution of the Greater Indian Landmass: A critical perspective; J. Indian Inst. Sci., https://doi.org/10.1007/s41745-018-0068-2.

Bose S, Fukuoka M, Sengupta P and Dasgupta S 2000 Evolution of high-Mg-Al granulites from sunkarametta, Eastern Ghats, India: Evidence for a lower crustal heating-cooling trajectory; J. Metamorph. Geol. 18 223-240.

Bose S, Pal S and Fukuoka M 2003 Pressure-temperaturefluid evolutionary history of orthopyroxene-bearing quartzofeldspathic and mafic granulites from northern parts of the Eastern Ghats belt, India: Implications for IndoAntarctic correlation; J. Asian Earth Sci. 22 81-100.

Bose S, Das K and Fukuoka M 2005 Fluorine content of biotite in granulite-grade metapelitic assemblages and its implications for the Eastern Ghats granulites; Eur. J. Mineral. 17 665-674.

Bose S, Das K, Dasgupta S, Miura H and Fukuoka M 2006 Exsolution textures in orthopyroxene in aluminous granulites as indicators of UHT metamorphism: New evidence from the Eastern Ghats belt, India; Lithos 92pg 506-523.

Bose S, Das K, Ohnishi I, Torimoto J, Karmakar S, Shinoda K and Dasgupta S 2009 Characterization of oxide assemblages of a suite of granulites from Eastern Ghats belt, India: Implication to the evolution of C-O-H-F fluids during retrogression; Lithos 113 483-497.

Bose S, Dunkley D J, Dasgupta S, Das K and Arima M 2011 India-Antarctica-Australia-Laurentia connection in the Paleoproterozoic-Mesoproterozoic revisited: Evidence from new zircon $\mathrm{U}-\mathrm{Pb}$ and monazite chemical age data from the Eastern Ghats belt, India; GSA Bull. $\mathbf{1 2 3}$ 2031-2049.

Bose S, Das K, Torimoto J, Arima M and Dunkley DJ 2016 Evolution of the Chilka Lake granulite complex, northern Eastern Ghats belt, India: First evidence of $\sim 780$ Ma decompression of the deep crust and its implication on the India-Antarctica correlation; Lithos 263pg 161-189.

Brown M 1994 The generation, segregation, ascent and emplacement of granite magma: The migmatite-tocrustally-derived granite connection in thickened orogens; Earth-Sci. Rev. 36 83-130.

Brown M 2001 Crustal melting and granite magmatism: Key issues; Phys. Chem. Earth A; Solid Earth Geod. 26 201-212.

Buddington A and Lindsley D 1964 Iron-titanium oxide minerals and synthetic equivalents; J. Petrol. 5 310-357.

Burton B P 1991 The interplay of chemical and magnetic ordering; Rev. Mineral. Geochem. 25 303-322.

Cameron E and Hattori K 1994 Highly oxidized deep metamorphic zones: Occurrence and origin; Mineral. Mag. A 58 142-143.

Cameron E M, Cogulu E H and Stirling J 1993 Mobilization of gold in the deep crust: Evidence from mafic intrusions in the Bamble belt, Norway; Lithos 30 151-166.

Carmichael I S 1991 The redox states of basic and silicic magmas: A reflection of their source regions? Contrib. Mineral. Petrol. 106 129-141.

Carroll M R and Rutherford M J 1987 The stability of igneous anhydrite: Experimental results and implications for sulfur behavior in the $1982 \mathrm{El}$ Chichon trachyandesite and other evolved magmas; J. Petrol. 28 781-801.

Crawford M and Hollister L 1986 Metamorphic fluids: The evidence from fluid inclusions. Fluid-rock interactions during metamorphism; Springer, NY, pp. 1-35.

Darken L and Gurry R 1945 The system iron-oxygen. I. The wüstite field and related equilibria; J. Am. Chem. Soc. 67 1398-1412.

Das K, Bose S, Karmakar S, Dunkley D J and Dasgupta S 2011 Multiple tectonometamorphic imprints in the lower crust: First evidence of ca. $950 \mathrm{Ma}$ (zircon U-Pb SHRIMP) compressional reworking of UHT aluminous granulites from the Eastern Ghats belt, India; Geol. J. $46217-239$.

Das K, Tomioka N, Bose S, Ando J and Ohnishi I 2017 The occurrence of fluor-wagnerite in UHT granulites and its implications towards understanding fluid regimes in the evolution of deep crust: A case study from the Eastern Ghats belt, India; Mineral. Petrol. $111417-429$.

Dasgupta S, Sengupta P, Guha D and Fukuoka M 1991 Mafic granulites from the Eastern Ghats, India: Further evidence for extremely high temperature crustal metamorphism; J. Geol. 99 124-133.

Dasgupta S, Sengupta P, Mondal A and Fukuoka M 1993 Mineral chemistry and reaction textures in metabasites from the Eastern Ghats belt, India and their implications; Mineral. Mag. 57 113-120.

Dasgupta S, Sengupta P, Ehl J, Raith M and Bardhan S 1995 Reaction textures in a suite of spinel granulites from Eastern Ghats belt, India: Evidence for polymetamorphism and a partial petrogenetic grid in the system KFMASH and the roles of $\mathrm{ZnO}$ and $\mathrm{Fe}_{2} \mathrm{O}_{3}$; J. Petrol. 36 435-461. 
Dasgupta S, Bose S and Das K 2013 Tectonic evolution of the Eastern Ghats belt, India; Precamb. Res. 227pg $247-258$

Dasgupta S, Bose S, Bhowmik S K and Sengupta P 2017 The Eastern Ghats belt, India, in the context of supercontinent assembly; In: Crustal evolution of India and Antarctica: The supercontinent connection (eds.) Pant N C and Dasgupta S, Geol. Soc. London Spec. Publ. 457 87-104.

Dobmeier C J and Raith M M 2003 Crustal architecture and evolution of the Eastern Ghats Belt and adjacent regions of India, in Yoshida M, Windley B F and Dasgupta S (eds.) Proterozoic East Gondwana: Supercontinent Assembly and Breakup; Geol. Soc. London Spec. Publ. 206 145-168.

Duchesne J C 1972 Iron-titanium oxide minerals in the Bjerkrem-Sogndal Massif, south-western Norway; J. Petrol. 13 57-81.

Dziggel A, Diener J F A, Stoltz N B and Kolb J 2012 Role of $\mathrm{H}_{2} \mathrm{O}$ in the formation of garnet coronas during near-isobaric cooling of mafic granulites: The Tasiusarsuaq terrane, southern West Greenland; J. Metamorph. Geol. 30 957-972.

Faryad S W and Hoinkes G 2004 Complex growth textures in a polymetamorphic metabasite from the Kraubath Massif (Eastern Alps); J. Petrol. 45 1441-1451.

Feisel Y, White R W and Palin R M 2018 New constraints on granulite-facies metamorphism and melt production in the Lewisian Complex, northwest Scotland; J. Metamorph. Geol., https://doi.org/10.1111/jmg.12311.

Frost B R 1991 Introduction to oxygen fugacity and its petrologic importance; Rev. Mineral. Geochem. 25 1-9.

Frost B R and Chacko T 1989 The granulite uncertainty principle: Limitations on thermobarometry in granulites; J. Geol. 97 435-450.

Frost B R, Lindsley D H and Andersen D J 1988 Fe-Ti oxidesilicate equilibria; assemblages with fayalitic olivine; $A m$. Mineral. 73 727-740.

Ganguly J 1979 Garnet and clinopyroxene solid solutions, and geothermometry based on Fe-Mg distribution coefficient; Geochim. Cosmochim. Acta 43 1021-1029.

Ganguly P, Bose S, Das K, Torimoto J and Ghosh G 2017 Origin of spinel+quartz assemblage in a Si-undersaturated ultrahigh-temperature aluminous granulite and its implication for the $\mathrm{P}-\mathrm{T}-$ fluid history of the phulbani domain, Eastern Ghats belt, India; J. Petrol. 58 1941-1974.

Ghiorso M S 1990 Thermodynamic properties of hematiteilmenite-geikielite solid solutions; Contrib. Mineral. Petrol. 104 645-667.

Gross A, Droop G T R and Porcer C C 2009 Petrology and thermobarometry of mafic granulites and migmatites from the Chafalote Metamorphic Suite: new insights into the Neoproterozoic P-T evolution of the Uruguayan-Sul-RioGrandense shield; Precamb. Res. 170 157-174.

Haggerty S E 1991 Oxide textures: A mini-atlas; Rev. Mineral. Geochem. 25 129-219.

Hall A 1986 Pyrite-pyrrhotite redox reactions in nature; Mineral. Mag. $50223-229$.

Hanor J S 1994 Origin of saline fluids in sedimentary basins; In: Geofluids: Origin, migration and evolution of fluids in sedimentary basins (ed.) Parnell J, Geol. Soc. London Spec. Publ. 78 151-174.
Hanor J S 2000 Barite-celestine geochemistry and environments of formation; In: Sulfate minerals: Crystallography, geochemistry and environmental significance (eds.) Hawthorne F C, Krivovichev V and Burns P C, Rev. Mineral. Geochem. 40 193-275.

Harley S 1989 The origins of granulites: A metamorphic perspective; Geol. Mag. 126 215-247.

Harley S 2008 Refining the $\mathrm{P}-\mathrm{T}$ records of UHT crustal metamorphism; J. Metamorph. Geol. 26 125-154.

Harlov D, Newton R C and Hansen E C 1997 Oxide and sulphide minerals in highly oxidized, Rb-depleted, Archaean granulites of the Shevaroy Hills Massif, south India: Oxidation states and the role of metamorphic fluids; $J$. Metamorph. Geol. 15 701-717.

Harlov D E 1992 Comparative oxygen barometry in granulites, Bamble Sector, SE Norway; J. Geol. 100 447-464.

Harlov D E 2000a Apparent pyrrhotite-chalcopyrite solid solutions in charnockites: The Shevaroy Hills Massif, Tamil Nadu, S India and the Bamble Sector, SE Norway; Mineral. Mag. 64 853-865.

Harlov D E 2000b Titaniferous magnetite-ilmenite thermometry and titaniferous magnetite-ilmeniteorthopyroxene-quartz oxygen barometry in granulite facies gneisses, Bamble Sector, SE Norway: Implications for the role of high-grade $\mathrm{CO}_{2}$-rich fluids during granulite genesis; Contrib. Mineral. Petrol. 139 180-197.

Harlov D E 2012 The potential role of fluids during regional granulite-facies dehydration in the lower crust; Geosci. Front. 3 813-827.

Harlov D E and Hansen E 2005 Oxide and sulphide isograds along a Late Archean, deep-crustal profile in Tamil Nadu, south India; J. Metamorph. Geol. 23 241-259.

Harlov D E, Johansson L, Van Den Kerkhof A and Förster H J 2005 The role of advective fluid flow and diffusion during localized, solid-state dehydration: Söndrum Stenhuggeriet, Halmstad, SW Sweden; J. Petrol. 47 3-33.

Harlov D E, Tropper P, Seifert W, Nijland T and Förster $\mathrm{H} \mathrm{J} 2006$ Formation of Al-rich titanite $\left(\mathrm{CaTiSiO}_{4} \mathrm{O}-\right.$ $\left.\mathrm{CaAlSiO}_{4} \mathrm{OH}\right)$ reaction rims on ilmenite in metamorphic rocks as a function of $\mathrm{fH}_{2} \mathrm{O}$ and $\mathrm{fO}_{2}$; Lithos 88 72-84.

Hartel T and Pattison D 1996 Genesis of the Kapuskasing (Ontario) migmatitic mafic granulites by dehydration melting of amphibolite: The importance of quartz to reaction progress; J. Metamorph. Geol. 14 591-611.

Hattori K and Cameron EM 1986 Archaean magmatic sulphate; Nature 319 45-47.

Huang G, Brown M, Guo J, Piccoli P and Zhang D 2018 Challenges in constraining the $\mathrm{P}-\mathrm{T}$ conditions of mafic granulites: An example from the northern Trans-North China Orogen; J. Metamorph. Geol., https://doi.org/10. $1111 /$ jmg. 12308 .

Jones K and Escher J 2002 Near-isothermal decompression within a clockwise $\mathrm{P}-\mathrm{T}$ evolution recorded in migmatitic mafic granulites from clavering $\varnothing, \mathrm{NE}$ Greenland: Implications for the evolution of the Caledonides; J. Metamorph. Geol. 20 365-378.

Kelsey D E, Morrissey L J, Hand M, Clark C, Tamblyn R, Gaehl A A and Marshall S 2017 Significance of post-peak metamorphic reaction microstructures in the ultrahigh temperature Eastern Ghats Province, India; J. Metamorph. Geol. 35 1081-1109. 
Keppler H 1996 Constraints from partitioning experiments on the composition of subduction-zone fluids; Nature $\mathbf{3 8 0}$ $237-240$.

Khodorevskaya L and Aranovich L Y 2016 Experimental study of amphibole interaction with $\mathrm{H}_{2} \mathrm{O}-\mathrm{NaCl}$ fluid at $900^{\circ} \mathrm{C}$, $500 \mathrm{MPa}$ : Toward granulite facies melting and mass transfer; Petrology 24 215-233.

Korhonen F J, Brown M, Clarke C and Bhattacharya S 2013a Osumilite--melt interactions in ultrahigh temperature granulites: Phase equilibria modelling and implications for the $\mathrm{P}-\mathrm{T}-\mathrm{t}$ evolution of the Eastern Ghats province, India; J. Metamorph. Geol. 31 881-907.

Korhonen F J, Clark C, Brown M, Bhattacharya S and Taylor R 2013b How long-lived is ultrahigh temperature (UHT) metamorphism? Constraints from zircon and monazite geochronology in the Eastern Ghats orogenic belt, India; Precamb. Res. 234 322-350.

Kretz R 1982 Transfer and exchange equilibria in a portion of the pyroxene quadrilateral as deduced from natural and experimental data; Geochim. Cosmochim. Acta 46 411421.

Kullerud G 1957 Phase relations in the Fe-SO system; Carnegie Inst. Wash. Yb. 56 198-200.

Lal R, Ackermand D and Upadhyay H 1987 P-T-X relationships deduced from corona textures in sapphirinespinel-quartz assemblages from Paderu, Southern India; J. Petrol. 28 1139-1168.

Lee H Y and Ganguly J 1988 Equilibrium compositions of coexisting garnet and orthopyroxene: Experimental determinations in the system $\mathrm{FeO}-\mathrm{MgO}-\mathrm{Al}_{2} \mathrm{O}_{3}-\mathrm{SiO}_{2}$, and applications; J. Petrol. 29 93-113.

Lindsley D H 1973 Delimitation of the hematite-ilmenite miscibility gap; GSA Bull. 84 657-662.

Lindsley D H 1991 Experimental studies of oxide minerals; In: Oxide minerals: Petrologic and magnetic significance (ed.) Lindsley D H, Rev. Mineral. 25 69-106.

López S and Castro A 2001 Determination of the fluidabsent solidus and supersolidus phase relationships of MORB-derived amphibolites in the range 4-14 kbar; Am. Mineral. 86 1396-1403.

Manning C and Aranovich L 2014 Brines at high pressure and temperature: Thermodynamic, petrologic and geochemical effects; Precamb. Res. 253 6-16.

Manning C E 2004 The chemistry of subduction-zone fluids; Earth Planet. Sci. Lett. 223 1-16.

McLelland J, Morrison J, Selleck B, Cunningham B, Olson C and Schmidt K 2002 Hydrothermal alteration of late-to post-tectonic Lyon Mountain Granitic Gneiss, Adirondack Mountains, New York: Origin of quartz-sillimanite segregations, quartz-albite lithologies, and associated Kirunatype low-Ti Fe-oxide deposits; J. Metamorph. Geol. 20 175-190.

Moecher D, Essene E J and Anovitz L M 1988 Calculation and application of clinopyroxene-garnet-plagioclasequartz geobarometers; Contrib. Mineral. Petrol. 100 92-106.

Mohan A, Sachan H K and Singh P K 2003 High-density carbonic fluid inclusions in charnockites from Eastern Ghats, India: Petrologic implications; J. Asian Earth Sci. 22 101-113.

Mohr D and Newton R C 1983 Kyanite-staurolite metamorphism in sulfidic schists of the Anakeesta formation, Great
Smoky Mountains, North Carolina; Am. J. Sci. $\mathbf{2 8 3}$ 97-134.

Möller P, Weise S M, Althaus E, Bach W, Behr H J, Borchardt R, Bräuer K, Drescher J, Erzinger J, Faber E, Hansen B T, Horn E E, Huenges E, Kämpf H, Kessels W and Kirsten T 1997 Paleofluids and recent fluids in the upper continental crust: Results from the German continental deep drilling program (KTB); J. Geophys. Res.: Solid Earth 102 18233-18254.

Montanini A and Tribuzio R 2001 Gabbro-derived granulites from the northern Apennines (Italy): Evidence for lowercrustal emplacement of tholeiitic liquids in post-Variscan times; J. Petrol. 42 2259-2277.

Muan A 1958 Phase equilibria at high temperatures in oxide systems involving changes in oxidation states; Am. J. Sci. 256 171-207.

Newton R C and Manning C E 2005 Solubility of anhydrite, $\mathrm{CaSO}_{4}$, in $\mathrm{NaCl}-\mathrm{H}_{2} \mathrm{O}$ solutions at high pressures and temperatures: Applications to fluid-rock interaction; J. Petrol. 46 701-716.

Ni H, Zhang L, Xiong X, Mao Z and Wang J 2017 Supercritical fluids at subduction zones: Evidence, formation condition, and physicochemical properties; Earth Sci. Rev. 167 62-71.

O'Brien P 2008 Challenges in high-pressure granulite metamorphism in the era of pseudosections: Reaction textures, compositional zoning and tectonic interpretation with examples from the Bohemian Massif; J. Metamorph. Geol. 26 235-251.

Ohmoto H and Kerrick D 1977 Devolatilization equilibria in graphitic systems; Am. J. Sci. 277 1013-1044.

Ohmoto H and Skinner B J 1983 The Kuroko and related volcanogenic massive sulfide deposits; Vol. 5, Econ. Geol. Publ. Co., New Haven

Padrón-navarta J, Garrido C J, Sánchez-Navas A, Tommasi A, López Sánchez-Vizcaíno V, Gómez-Pugnaire M T and Hussain S S 2008 Oriented growth of garnet by topotactic reactions and epitaxy in high-pressure, mafic garnet granulite formed by dehydration melting of metastable hornblende-gabbronorite (Jijal Complex, Kohistan Complex, north Pakistan); J. Metamorph. Geol. 26 855-870.

PatiñoDouce A E and Beard J S 1995 Dehydration-melting of biotite gneiss and quartz amphibolite from 3 to $15 \mathrm{kbar}$; J. Petrol. 36 707-738.

Pattison D R M 1991 Infiltration-driven dehydration and anatexis in granulite facies meragabbro, Grenville Province, Ontario, Canada; J. Metamorph. Geol. 9315 332.

Pattison D R M 2003 Petrogenetic significance of orthopyroxene-free garnet + clinopyroxene + plagioclase \pm quartz-bearing metabasites with respect to the amphibolite and granulite facies; J. Metamorph. Geol. 21 21-34.

Pattison D R M, Chacko T J, Farquhar J and McFarlane C R M 2003 Temperatures of granulite-facies metamorphism: Constraints from experimental phase equilibria and thermobarometry corrected for retrograde exchange; J. Petrol. 44 867-900.

Pownceby M I, Wall V J and O'Neill HSt 1987 Fe-Mn partitioning between garnet and ilmenite: Experiments and applications; Contrib. Mineral. Petrol. 97 116126 . 
Racek M, Štípská P and Powell R 2008 Garnetclinopyroxene intermediate granulites in the St. Leonhard massif of the Bohemian massif: Ultrahigh-temperature metamorphism at high pressure or not? J. Metamorph. Geol. 26 253-271.

Ramakrishnan M, Nanda J K and Augustin P 1998 Geological evolution of the proterozoic Eastern Ghats mobile belt; In: Geological evolution of proterozoic Eastern Ghats Mobile belt (eds.) Ramakrishnan M, Paul D K and Mishra R N, Geol. Surv. India Spec. Publ. 44 1-21.

Ranjan S, Upadhyay D, Pruseth K L and Nanda J K 2018 Zircon geochronology of deformed alkaline rocks along the Eastern Ghats belt margin: India-Antarctica connection and the Enderbia continent; Precamb. Res., https://doi. org/10.1016/j.precamres.2018.04.005.

Rapp R P and Watson E B 1995 Dehydration melting of metabasalt at 8-32 kbar: Implications for continental growth and crust-mantle recycling; J. Petrol. 36 891-931.

Rapp R P, Bruce E, Calvin W and Miller F 1991 Partial melting of amphibolite/eclogite and the origin of Archean trondhjemites and tonalities; Precamb. Res. 51 1-25.

Rickers K, Mezger K and Raith M M 2001 Evolution of the continental crust in the Proterozoic Eastern Ghats Belt, and new constraints for Rodinia reconstruction: Implications from $\mathrm{Sm}-\mathrm{Nd}, \mathrm{Rb}-\mathrm{Sr}$ and $\mathrm{Pb}-\mathrm{Pb}$ isotopes; Precamb. Res. 112 183-210

Rittenhouse G 1967 Bromine in oil-field waters and its use in determining possibilities of origin of these waters; $A A P G$ Bull. 51 2430-2440.

Rollinson H R 1980 Iron-titanium oxides as an indicator of the role of the fluid phase during the cooling of granites metamorphosed to granulite grade; Mineral. Mag. 43 623-631.

Rushmer T 1991 Partial melting of two amphibolites: Contrasting experimental results under fluid-absent conditions; Contrib. Mineral. Petrol. 107 41-59.

Rushmer T 1993 Experimental high-pressure granulites: Some applications to natural mafic xenolith suites and Archean granulite terranes; Geology 21 411-414.

Saha T and Karmakar S 2015 Petrotectonic framework of granitoids and associated granulites at Nagavalli Shear Zone (NSZ), Eastern Ghats belt: Evidence of a late transpression orogeny; J. Earth Syst. Sci. 124 707-727.

Sarkar S, Santosh M, Dasgupta S and Fukuoka M 2003 Very high density $\mathrm{CO}_{2}$ associated with ultrahigh-temperature metamorphism in the Eastern Ghats granulite belt, India; Geology 31 51-54.

Sawyer E 1999 Criteria for the recognition of partial melting; Phys. Chem. Earth A; Solid Earth Geod. 24 269-279.

Sen C and Dunn T 1994 Dehydration melting of a basaltic composition amphibolite at 1.5 and $2.0 \mathrm{GPa}$ : Implications for the origin of adakites; Contrib. Mineral. Petrol. 117 394-409.

Sengupta P, Dasgupta S, Bhattacharya P K, Fukuoka M, Chakraborti S and Bhowmick S 1990 Petro-tectonic imprints in the sapphirine granulites from Anantagiri, Eastern Ghats mobile belt, India; J. Petrol. 31 971-996.

Sengupta P, Dasgupta S, Bhui U K, Ehl J and Fukuoka M 1996 Magmatic evolution of mafic granulites from Anakapalle, Eastern Ghats, India: Implications for tectonic setting of a Precambrian high-grade terrain; J. Southeast Asian Earth Sci. 14 185-198.
Shaw R K, Arima M, Kagami H, Fanning C M, Shiraishi K and Motoyoshi Y 1997 Proterozoic events in the Eastern Ghats granulite belt, India: Evidence from $\mathrm{Rb}-\mathrm{Sr}$, Sm-Nd systematics, and SHRIMP dating; J. Geol. 105 645-656.

Shikazono N, Holland H D and Quirk R F 1983 Anhydrite in Kuroko deposits: Mode of occurrence and depositional mechanisms; Econ. Geol. Mon. 5 329344 .

Shmulovich K I and Graham C M 2004 An experimental study of phase equilibria in the systems $\mathrm{H}_{2} \mathrm{O}-\mathrm{CO}_{2}-\mathrm{CaCl}_{2}$ and $\mathrm{H}_{2} \mathrm{O}-\mathrm{CO}_{2}-\mathrm{NaCl}$ at high pressures and temperatures $\left(500-800^{\circ} \mathrm{C}, 0.5-0.9 \mathrm{GPa}\right)$ : Geological and geophysical applications; Contrib. Mineral. Petrol. 146 450462.

Skjerlie K P and PatinõDouce A 1995 Anatexis of interlayered amphibolite and pelite at 10 kbar: Effect of diffusion of major components on phase relations and melt fraction; Contrib. Mineral. Petrol. 122 62-78.

Springer W and Seck H A 1997 Partial fusion of basic granulites at 5 to 15 kbar: Implications for the origin of TTG magmas; Contrib. Mineral. Petrol. 127 30-45.

Stober I and Bucher K 2005 The upper continental crust, an aquifer and its fluid: Hydaulic and chemical data from 4 $\mathrm{km}$ depth in fractured crystalline basement rocks at the KTB test site; Geofluids $\mathbf{5}$ 8-19.

Stormer J C and Whitney J A 1977 Two-feldspar geothermometry in granulite facies metamorphic rocks; Contrib. Mineral. Petrol. 65 123-133.

Stout M, Crawford M L and Ghent E D 1986 Pressuretemperature and evolution of fluid compositions of $\mathrm{Al}_{2} \mathrm{SiO}_{5}$-bearing rocks, mica creek, $\mathrm{BC}$, in light of fluid inclusion data and mineral equilibria; Contrib. Mineral. Petrol. 92 236-247.

Török K, Bali E, Szabó C and Szakál J A 2003 Sr-barite droplets associated with sulfide blebs in clinopyroxene megacrysts from basaltic tuff (Szentbékkálla, western Hungary); Lithos 66 275-289.

Toulmin P and Barton P B 1964 A thermodynamic study of pyrite and pyrrhotite; Geochim. Cosmochim. Act $\mathbf{2 8}$ 641-671.

Touret J L 1985 Fluid regime in southern Norway: The record of fluid inclusions. The deep proterozoic crust in the north Atlantic provinces; Springer, Dordrecht, pp. 517-549.

Touret J L 2009 Mantle to lower-crust fluid/melt transfer through granulite metamorphism; Russ. Geol. Geophys. 50 1052-1062.

Touret J L and Huizenga J M 2012 Fluid-assisted granulite metamorphism: A continental journey; Gondwana Res. $21224-235$.

Touret J L and Nijland T 2013 Prograde, peak and retrograde metamorphic fluids and associated metasomatism in upper amphibolite to granulite facies transition zones. Metasomatism and the chemical transformation of rock; Springer, Berline, Heidelberg, pp. 415-469.

Tracy R J and Robinson P 1988 Silicate-sulfide-oxide-fluid reactions in granulite-grade pelitic rocks, central Massachusetts; Am. J. Sci. 288 45-74.

Upadhyay D 2008 Alkaline magmatism along the southeastern margin of the Indian shield: Implications for regional geodynamics and constraints on craton-Eastern Ghats belt suturing; Precamb. Res. 162 59-69. 
Valenza K, Moritz R, Mouttaqi A, Fontignie D and Sharp Z 2000 Vein and karst barite deposits in the Western Jebilet of Morocco: Fluid inclusion and isotope ( $\mathrm{S}, \mathrm{O}, \mathrm{Sr}$ ) evidence for regional fluid mixing related to Central Atlantic Rifting; Econ. Geol. 95 587-606.

Van Cranendonk M J and Pirajno F 2004 Geochemistry of metabasalts and hydrothermal alteration zones associated with c. $3.45 \mathrm{Ga}$ chert and barite deposits: Implications for the geological setting of the Warrawoona Group, Pilbara Craton, Australia; Geochem. Explor. Envir. Anal. 4253 278.

Vincent E and Phillips R 1954 Iron-Titanium oxide minerals in layered gabbros of the skaergaard intrusion, east Greenland: Part I. Chemistry and ore-microscopy; Geochim. Cosmochim. Acta 6 1-26.

Watson E B and Brenan J M 1987 Fluids in the lithosphere, 1. Experimentally-determined wetting characteristics of $\mathrm{CO}_{2}-\mathrm{H}_{2} \mathrm{O}$ fluids and their implications for fluid transport, host-rock physical properties, and fluid inclusion formation; Earth Planet. Sci. Lett. 85 497-515.
Wolf M B and Wyllie P J 1994 Dehydration-melting of amphibolite at $10 \mathrm{kbar}$ : The effects of temperature and time; Contrib. Mineral. Petrol. 115 369-383.

Yardley B W D 2005 Metal concentrations in crustal fluids and their relationship to ore formation; Econ. Geol. 100 613-632.

Yardley B W 2009 The role of water in the evolution of the continental crust; J. Geol. Soc. London 166 585-600.

Yardley B and Graham J 2002 The origins of salinity in metamorphic fluids; Geofluids 2 249-256.

Yund R A and Kullerud G 1966 Thermal stability of assemblages in the Cu-Fe-S system; J. Petrol. 7 454-488.

Zhang H, Ling M, Liu Y, Tu X, Wang F, Li C, Liang H, Yang X, Arndt N and Sun W 2013 High oxygen fugacity and slab melting linked to $\mathrm{Cu}$ mineralization: Evidence from dexing porphyry copper deposits, southeastern China; $J$. Geol. 121 289-305.

Zheng Y, Ren C, Zheng X and Shao Z 2016 The transport of water in subduction zones; Sci. China Earth Sci. $\mathbf{5 9}$ 651-682.

Corresponding editor: PUlak SEngupta 